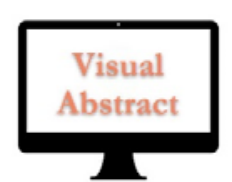

\title{
Experimental and numerical optimization study of shock wave damping in aluminum panel sandwich
}

\author{
Masoud Rahmani, Amin Moslemi Petrudi \\ Department of Mechanical Engineering, Tehran University, Iran \\ msrabmani@ibu.ac.ir, bttp://orcid.org/0000-0002-0519-0670 \\ amin.moslemi2020@gmail.com, bttp:/ /orcid.org/0000-0002-5928-0479
}

\begin{abstract}
Sandwich panels with polymer composite and light core composites are widely used in aircraft and spacecraft, vessels, trains, submarines, and cars. Due to their high strength to weight ratio, high stability, and high corrosion resistance, these structures have become particularly important in the industry. Reduction in impact energy, shock waves, and noise in many industries, including the automotive and military industries. Porous materials have always been the focus of attention due to their shock-reducing effects in various protective applications. For this reason, the study of physics governing shock propagation problems in porous media is of particular importance, and the complexity of the governing equations also results in the numerical solution of these equations with many computational problems and costs. In this paper, shock wave damping is investigated numerical and experimental in aluminum blocks with porous grains scattered inside aluminum. The deformations of the specimens in numerical simulation and experimental testing have been compared. The results show that this material behaves similarly to the aluminum foam in both static loadings (practical pressure testing) and dynamic loading (explosion) results, again similar to aluminum foam.
\end{abstract}

KEYwords. Sandwich Panel; Shock Wave; Blast; Aluminum Foam; Porous material.

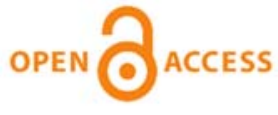

Citation: Rahmani, M., Petrudi, A. M., Experimental, numerical, and optimization study of shock wave damping in aluminum panel sandwich, Frattura ed Integrità Strutturale, 55 (2021) 88-109.

Received: 04.10 .2020

Accepted: 30.10 .2020

Published: 01.01.2021

Copyright: (C) 2021 This is an open-access article under the terms of the CC-BY 4.0, which permits unrestricted use, distribution, and reproduction in any medium, provided the original author and source are credited.

\section{INTRODUCTION}

$\mathrm{S}$ andwich Panel is a lightweight, composite structure with a high bearing capacity of tensile, compressive, bending, and torsional loads, which is limited to two face sheets on both sides and is located in the middle of a layer called Core. Face sheets are made of materials with high hardness, strength, and density, such as metal, polymer, composite, and nanocomposite, while the core is often a material with a lower density and stiffness than face sheets. The core made of Foam, Honeycomb, and Truss shapes. Two specimens of panel sandwiches with foam cores and honeycomb nests are shown in Fig. 1 [1, 2]. High-strength lightweight sandwich panels were first used to build warplane hangars during World War II. Since then, and with significant advances in the design and manufacture of these materials, sandwich panels have 
been widely used in the construction of space shuttles, ship body, and aircraft body. These structures may be subject to Low-Velocity Impact (LVI) and High-Velocity Impact loading types. Metal foams and porous materials are the materials that have shown good behaviour in the field of impact absorption as the core of sandwich panels. So far, studies on the transmission of shock waves and impact in porous materials have been conducted by various researchers. They investigated the effect of various factors on the propagation speed of the wave [7, 8]. Factors such as specimen width, damping ratio, particle shape, particle arrangement, vibration frequency, particle diameter and hardness, particle size, and coefficient of friction between particles, pressure or depth are the parameters most of which have been studied and simulated by various researchers [5-7]. However, despite significant research on wave propagation and the parameters affecting it, there are still several factors that may affect wave propagation in granular materials that have not been studied to determine their effect on the wave propagation process $[8,9]$. There has also been a lot of research on the depreciation of the blast wave in metal foams due to the widespread use of these materials as energy absorbers. Irie et al. [10] examined the dynamic properties of aluminum foam. High impact strain tests and numerical simulations were used to investigate the power of these materials in energy absorption. Hangai et al. [11] studied the effect of porosity and structural cavities on the compressive properties of cast aluminum foam. Shim et al. [12] studied shock waves in structures protected with aluminum foam panels and experimental testing and simulation with LS-Dyna software were used in this study. Vesenjak et al. [13] Investigated the behaviour of metal foams under shock loading. In this study, they used numerical simulation and experimental testing. Mahmoud et al. [14] Investigated the Behavior of reinforced concrete slabs with aluminum foam sheets under blast load. Goel et al. [15] Investigated the impact of the shock wave with closed aluminum foam. In this study, the shock tube was used for experimental testing. The effect of increasing the specimen thickness on wave reduction and using the specimen as a sandwich panel was studied. It has been proven that the density of the foam and the thickness, as well as the placement of the coating plates of the same material on the front and back of the foam, have a significant effect on the shock pressure reflected. Barthelemy et al. [16] developed and studied a micromechanical model for considering the effects of micro-inertia on the microscopic behaviour of closed metal foams under dynamic loading conditions. Comparing the results with the experimental data, it has been observed that considering the effects of micro-inertia results in a better description of the foam shock response, indicating that the micro-inertia may have a significant effect on the dynamic behaviour of metal foams. Radford et al. Dynamic response of panels consisting of two sheets of stainless steel AISI304 and the middle layer of aluminum foam and fully supported supports to the central impact of projectiles with a length of $50 \mathrm{~mm}$ and a diameter of $28 \mathrm{~mm}$ of aluminum foam with speeds of $160-570 \mathrm{~m} / \mathrm{s}$ are thrown from of the gas gun. They have studied the dynamic resistance of sandwich panels and single-layer steel plates with the same weight and research on the effect of the thickness of the middle foam layer on the strength of the panel [17]. Closed-cell aluminum foam based on pure aluminum was used to design and manufacture the shock-absorbing layer for the tunnel lining by Su et al [18]. The feasibility of using a closed-cell aluminum foam layer as a damping design for tunnel lining was tested using a large-scale shaking table. Results showed that the closed-cell aluminum foam layer weakened the dynamic response of the tunnel lining. Fall drop impact test for closed-cell aluminum foams was conducted experimentally and numerically by Taherkhani et al [19] According to their study, cells are categorized into two different groups in terms of their locations including the cells were affected by the impact and the cells are far from the impact location. Deformation mechanisms of the first group were bending and buckling and the second group cells were not affected by the impact. Low density, high rigidity aluminum foam, and Specific Stiffness Strength make the use of metal foams very common in the manufacture of sandwich panels, car bodies, and modern aircraft, as well as floating structures [20, 21]. Low resistance and high compressive strain, which usually occur at constant stresses, have created a lot of appeal for impact absorption applications [22, 23]. As the momentum enters the adjacent layer, the first layer absorbs part of the impact energy, transfers the rest to the adjacent layer, and this repetitive and continuous process that starts from the surface of the collision and progresses along the axis of the specimen [24]. Thus, unlike static loading, where cell collapse occurs in discrete strips, plastic collapse occurs at impact loading at the Shock Front location and progresses at the speed of wave motion [25, 26]. Fig. 2 shows cells collapse in impact loading. This paper examines a structure similar to aluminum foam. This sandwich structure consists of an aluminum core in which porous particles are dispersed. The purpose of this structure is to study the similarity of its properties with aluminum foam, which many applications in the absorption of shock and sound energy. Aluminum foam is one of the most advanced materials and the cost of making aluminum foam according to the required devices and manufacturing process is almost high, so aluminum panels with porous grains can be replaced by aluminum foam in some applications due to lower manufacturing costs. Aluminum casting on mineral pumice particles with specific granulation has been used to make the specimen. For modeling, standard compressive specimens were first developed and tested. Using compression diagrams, the mechanical properties required for simulation were extracted and introduced to the software. 


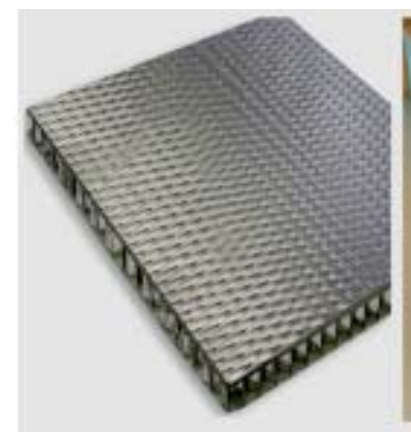

(a)

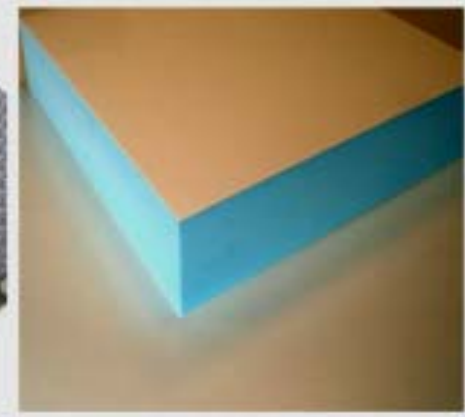

(b)

Figure 1: Sandwich panel with core, a) Honeycomb b) Foam.

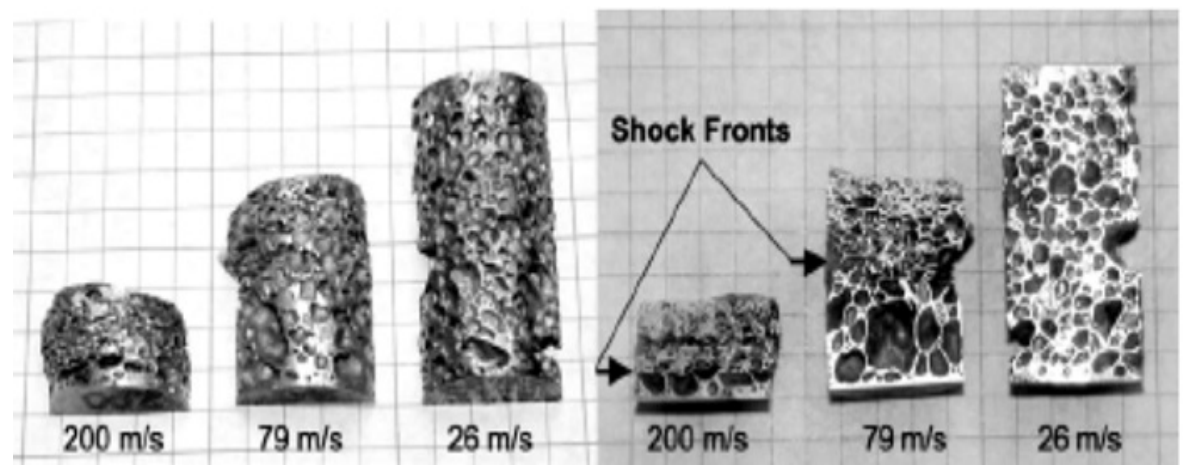

Figure 2: Cells collapse in impact loading [10].

Impact-Induced Shock Propagation or Blast-Induced Shock Propagation is quite similar, and there are only differences in the boundary conditions of the problem. Fig. 3 shows impact absorption into a metal foam.

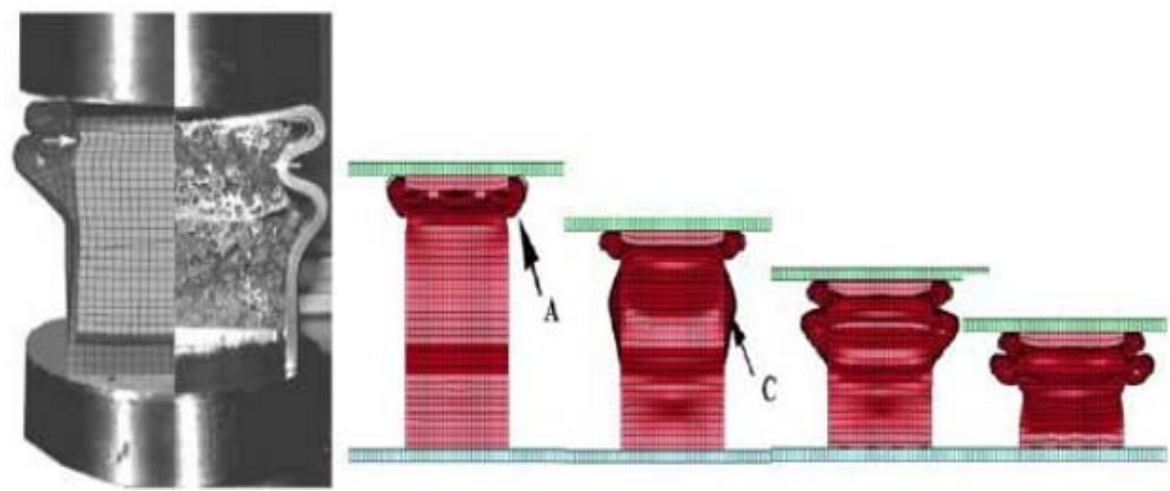

Figure 3: Impact absorption into a metal foam.

\section{SHOCK TUBE}

hock tubes are a tool for conducting explosive waves and simulating real explosions and their effects, which are

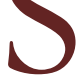
usually used on a small scale. Shock tubes are also used to study the phenomena of compression flow and the combustion reaction of the gas phase. The shock wave inside a shock tube is generated by a small explosion (guided explosion) or by an increase in pressure that causes the diaphragm to collapse and propagate a compressed gas shock wave. Fig. 4 shows a picture of a laboratory explosive shock tube. 
The first studies using the shock tube were published in 1899 by French scientists Paul Vieille, but the machine was not known as the shock tube until the 1940s [27]. Interest in studying the rapid movement of gases on objects using shock tubes increased. In 1966, Duff and Blackwell introduced an explosive shock tube that generates a shock wave caused by an explosive [28]. Both compression and explosive shock tubes are used for scientific studies in the military and research center. It is much easier to use and operate a pressure shock pipe in a laboratory setting, but the shape of the pressure wave produced by an explosion in an explosion shock pipe is different. Therefore, for some studies, the pressure shock tube cannot be useful. Fig. 5 shows the compression and explosive shock pipes.

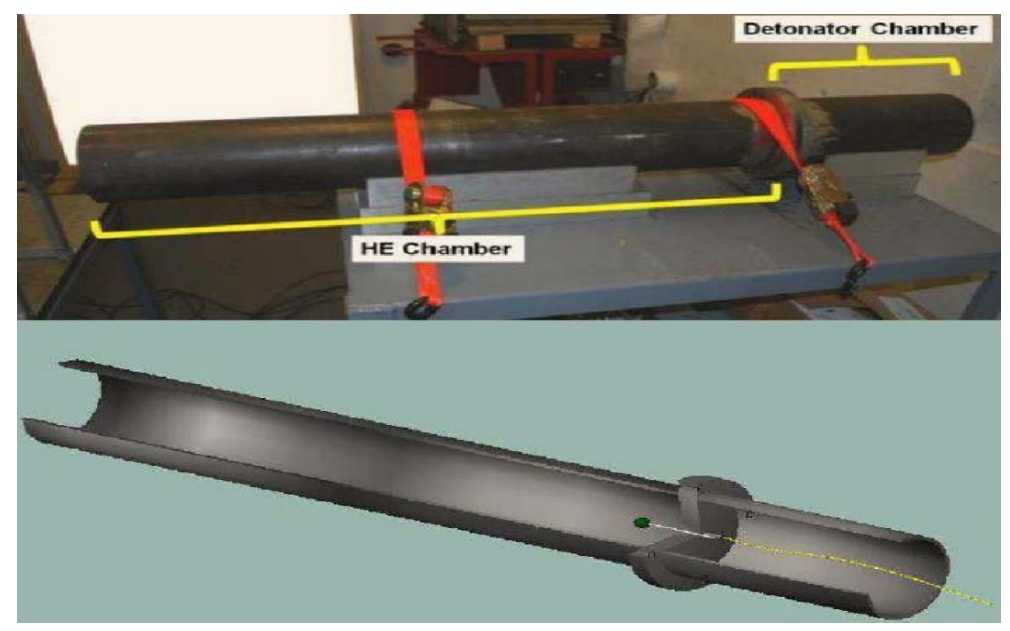

Figure 4: Laboratory Explosive Shock Pipe.

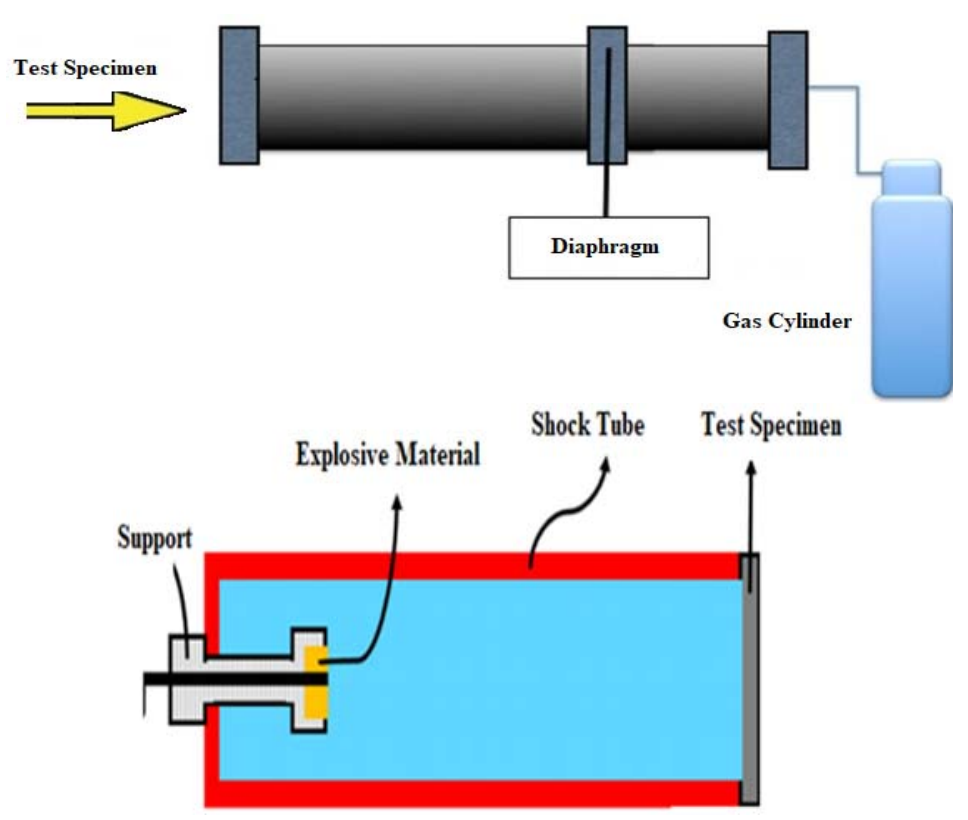

Figure 5: Schematic of compression and explosive shock pipes.

\section{EXPERIMENTAL TEST}

$\mathrm{F}$ ig. 6 shows the different types of pumice grains. According to the diagrams obtained for the specimens of the pressure test and the similarity of the article results with the results of the aluminum foam pressure test, some behaviours of the material are predicted. According to the articles and studies that have investigated explosive loading and impact on aluminum foam specimens, the use of the P-alpha model equation of state, von Mises strength model, and minimum 
pressure failure model is suitable for aluminum foams. Due to the similarity of the stress-strain diagram, the specimens of this study are predicted with aluminum foam. This material has relatively similar behaviours to aluminum foam in behaviours with the blast wave, but it is difficult to define some parameters in this method. Explosion tests have been used in this study.

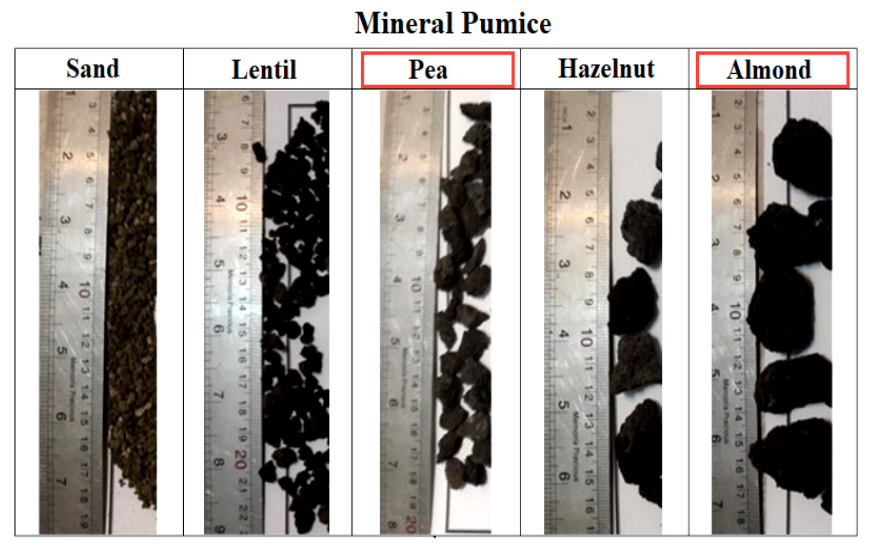

Figure 6: Various granulation of pumices.

In this study, two sizes of almond mineral pumice (maximum dimensions of $3 \mathrm{~cm}$ ) and pea mineral pumice (maximum dimensions of $1 \mathrm{~cm}$ ) are used and two types of pumice with grey colour are used. Fig. 7 shows an almond granular pumice. Fig. 8 shows how to make test specimens.

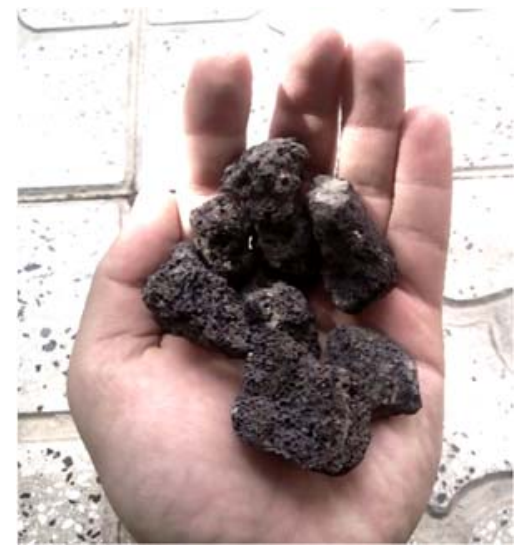

A) Scoria mineral pumice

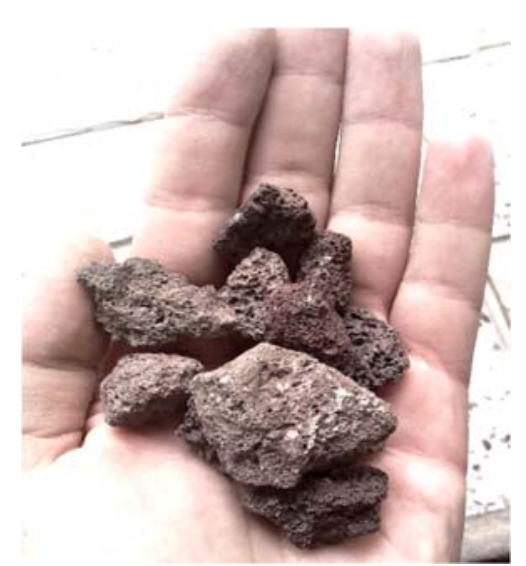

B) Pumice mineral pumice

Figure 7: Almond granulation pumice.

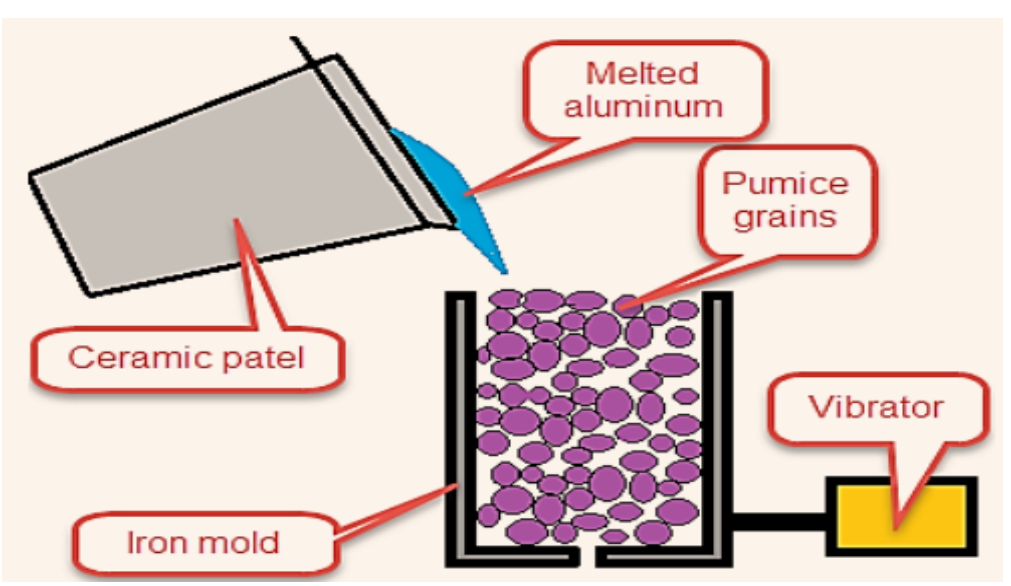

Figure 8: Made test specimens 
According to the purpose of this study, which is to replace the structure with aluminum foam, the method of deformation of pressure test specimens is compared with the testing of pressures performed on aluminum foam in articles. Fig. 9 shows the pressure test specimens after the test. Fig. 10 shows how the same specimens are deformed in the aluminum foam under the pressure test. For a better comparison, the stress-strain diagram for a specimen of aluminum with porous pumice particles can be shown in Figs. 11 and 12, which is based on stress-strain diagrams of the specimens obtained in the pressure test. There are similarities with the behaviour of aluminum foam in the porosity of less than $50 \%$ of aluminum foam, so the equations used for aluminum foam have been used to simulate the specimens in this study.

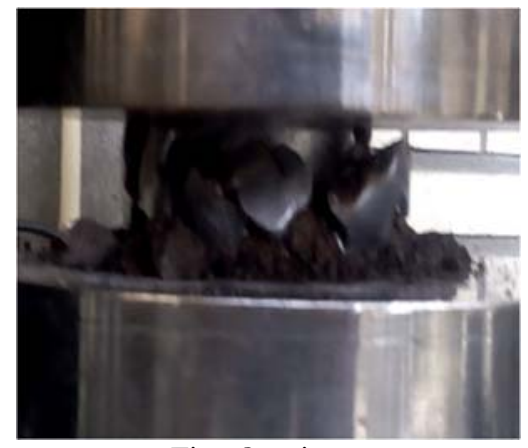

First Specimen

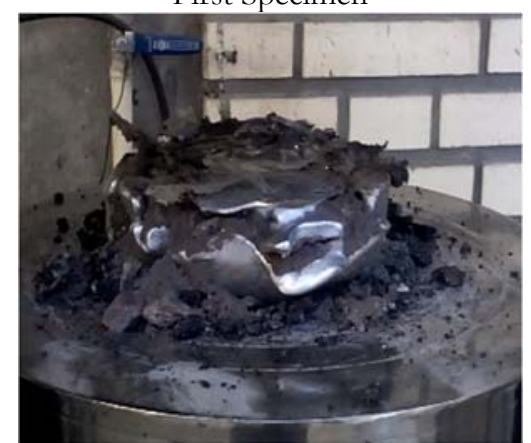

Third Specimen

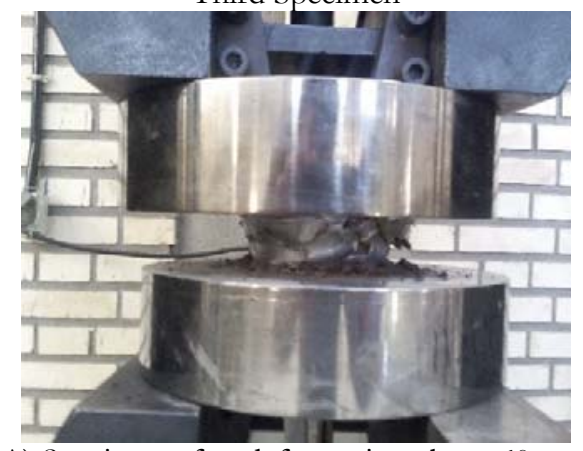

A) Specimen after deformation about $60 \mathrm{~mm}$

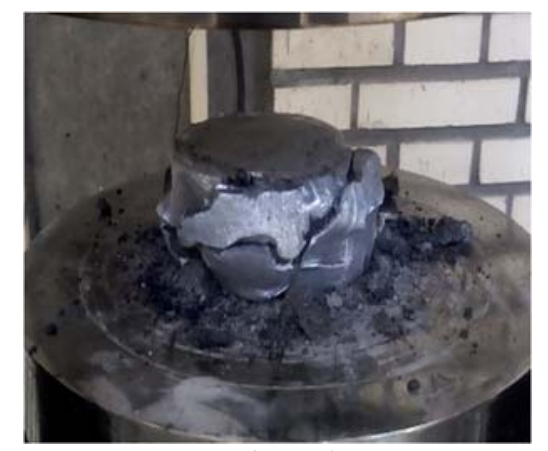

Second Specimen

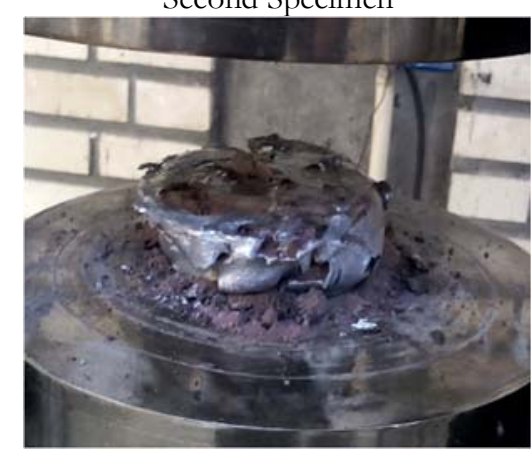

Fourth Specimen

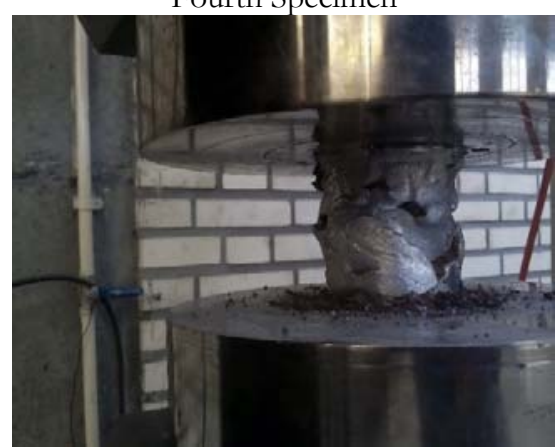

B) Specimen after deformation about $27 \mathrm{~mm}$

Figure 9: Experimental specimens in the pressure test.
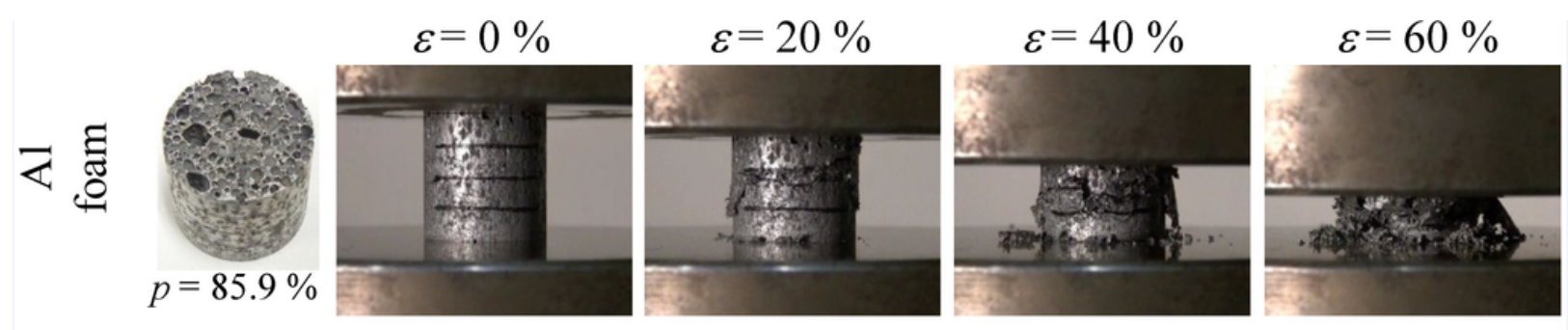

Figure 10: Aluminum foam specimen after pressure test [1]. 


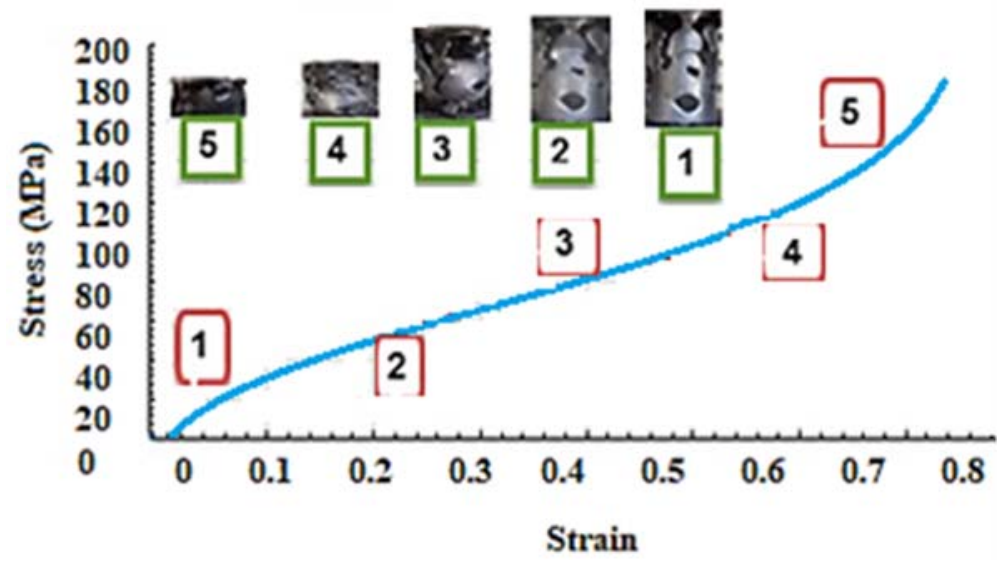

Figure 11: Stress-strain for an aluminum foam specimen.

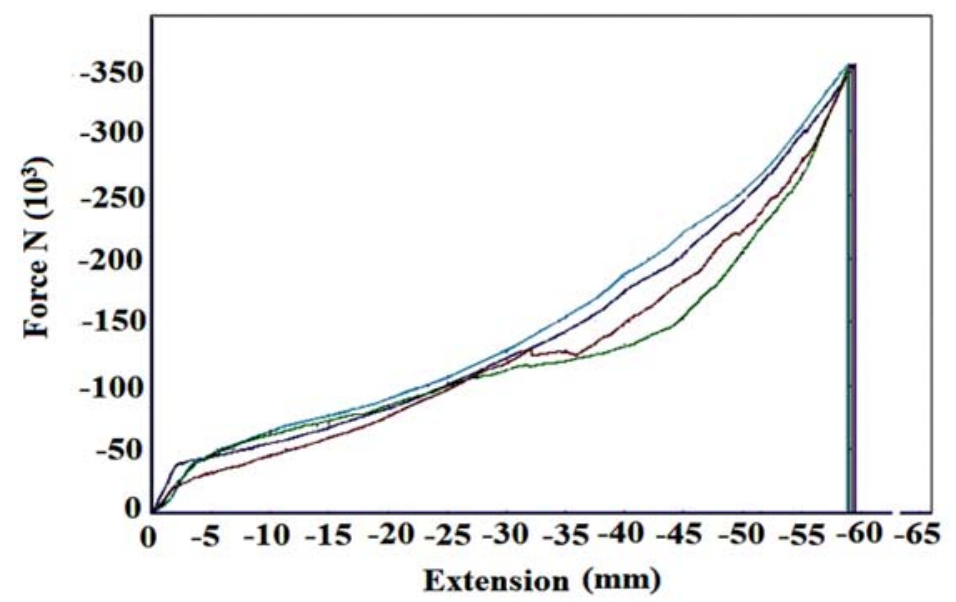

Figure 12: Comparison of displacement and force diagrams of different specimens.

Fig. 13 shows the shock tube used for the experimental test and the location of the explosive charge as well as the location of the specimen.

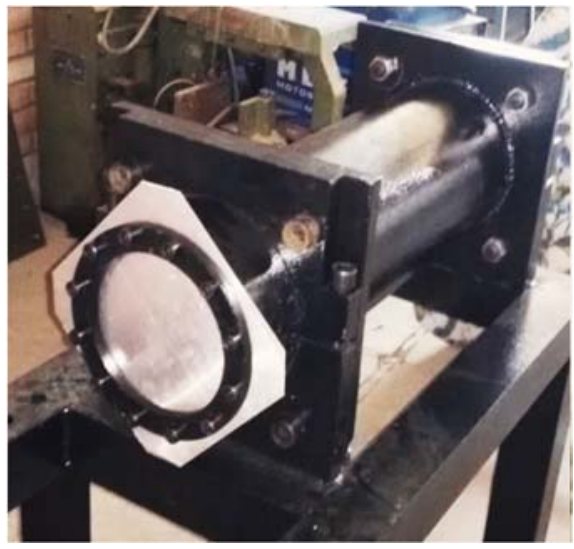

Location of the specimen on the shock tube

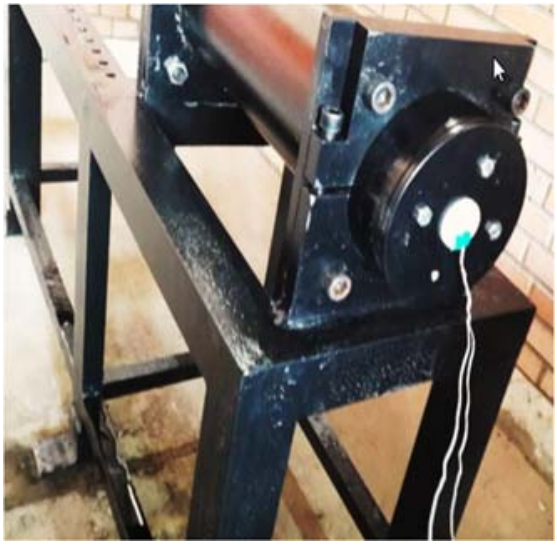

Location of the explosive charge and electric detonator

Figure 13: Shock tube. 
To perform numerical simulation, we need to define the equation of state, strength model, and failure model, which are determined according to the properties and Behavior of the material. the following is an explanation of the equations for the simulation materials in this study.

\section{EQUATION OF STATE OF EXPLOSIVE MATERIAL}

he method of interpreting the initiation, expansion, and expansion of explosives depends entirely on the material being studied. The numerical model used for explosives is fully tested and reliable.

\section{JWL equation of state}

In this equation, it is assumed that the explosive will explode completely. Jones-Wilkins-Lee equation of state is used to model the pressure generated by the increase in chemical energy in an explosion. This equation of state is usually recommended for the interaction of metals with the pressure from an explosion. Equation of state is used to model an explosive in simulating this paper. The pressure produced is obtained in relation (1):

$$
p=A\left(1-\frac{\omega \rho}{\mathrm{R}_{1} \rho_{0}}\right) \exp \left(-\mathrm{R}_{1} \frac{\rho_{0}}{\rho}\right)+B\left(1-\frac{\omega \rho}{\mathrm{R}_{2} \rho_{0}}\right) \exp \left(-\mathrm{R}_{2} \frac{\rho_{0}}{\rho}\right)+\omega \rho E_{m}
$$

In this case, $A, B, R_{1}, R_{2}$, and $\omega$ are the material constants that are defined by the user; $\rho_{0}$ is the density of the explosion and $\rho$ is the density of the explosive. The input variables for this state equation for different explosives are shown in Tab. 1.

\begin{tabular}{|c|c|c|c|c|c|}
\hline $\begin{array}{c}\text { Explosive } \\
\text { Material }\end{array}$ & $\begin{array}{c}\omega \\
\text { (Dimensionless) }\end{array}$ & $\begin{array}{c}\mathrm{R}_{1} \\
\text { (Dimensionless) }\end{array}$ & $\mathrm{R}_{2}$ (Dimensionless) & $\mathrm{B}(\mathrm{GPa})$ & $\mathrm{A}(\mathrm{GPa})$ \\
\hline PETN & 0.28 & 1.8 & 6 & 20.16 & 573.1 \\
\hline TNT & 0.3 & 0.95 & 4.15 & 3.23 & 371.2 \\
\hline Comp C-4 & 0.25 & 1.4 & 4.5 & 12.95 & 609.77 \\
\hline
\end{tabular}

Table 1: JWL Equation of state parameters for several explosive materials [29].

In this article, $\mathrm{C} 4$ explosive is used.

\section{Ideal gas equation of state}

One of the simplest forms of the equation of state is the ideal gas, which is used in many applications related to the motion of gases. This equation is derived from the rules of Boyle and Gay-Lussac, which are expressed with (2).

$$
p=(\gamma-1) \rho e
$$

This equation of state form is known as the ideal gas equation, and only the value of the adiabatic coefficient $\gamma$ must be determined. Eqn. (2) is modified as Eqn. (3).

$$
p=(\gamma-1) \rho e-p_{s h i f t}
$$

In this relation $p_{\text {shiff }}$, a small initial pressure is defined as the initial zero pressure. By defining a non-zero $\mathrm{C}$ adiabatic constant, the equation of state for the energy-dependent gas converts the ideal gas into a non-dependent adiabatic equation of state (4).

$$
p=c \rho^{\gamma}
$$

In simulating the problem of this article, the ideal gas state equation has been used for air modeling [29]. 


\section{P-Alpha equation of state}

Piecewise-linear porous model gives good results for low pressures. But need to have a model for interpreting high velocity and different materials. This model was introduced by Herrmann [30] and has been added to the Autodyn software. PAlpha model is designed to compress brittle porous materials. The porosity of the material with $\mathrm{n}$ is shown as the ratio of the volume of the cavities $\left(V_{\mathrm{p}}\right)$ to the total volume $\left(\mathrm{V}=\mathrm{V}_{\mathrm{p}}+\mathrm{V}_{\mathrm{s}}\right)$, which $\mathrm{V}_{\mathrm{s}}$ is the volume of the solid part of the material. It is $0 \leq=\alpha 1$ the porosity range that shows the zero state of complete compression. Therefore, it is necessary to define the $a$ scalar variable, sometimes called Distension, as the density of the solid material like the density of the porous material. $\alpha$ defined in terms of $\mathrm{n}$, which show in Eqn. (5):

$$
\alpha=\frac{\rho_{s}}{\rho}+=\frac{v}{v_{s}}=\frac{1}{1-n}
$$

where $v$ is the specific volume of the porous material and $v_{s}$ is the specific volume of the solid at the same temperature and pressure. If the equation of state solid material is as follows:

$$
p=f(v, e)
$$

In this model, the equation of state of the porous material is as follows:

$$
p=f\left(\frac{v}{\alpha}, e\right)
$$

That $f$ is the same in both of these equations. This function a multi-component linear and shock function, but it cannot use the expansion equation of state. The value of $a$ should be written using thermodynamic relations as follows:

$$
\alpha=g(p, e)
$$

There is usually not enough information to calculate the function of $g(p, e)$, but many of the problems in the study of shock in porous materials are such that the behaviour of material using Hugoniot's equations is as follows:

$$
\alpha=g(\mathrm{P})
$$

$P$ - $a$ relations the material is compressed under elastic to $P_{\mathrm{e}}$ pressure and then completely compressed to $P_{\mathrm{n}}$. Fig. 14 shows the behaviour of the material with the P-alpha equation of state in loading and unloading (according to the equation, it is clear that $\alpha$ is dimensionless).

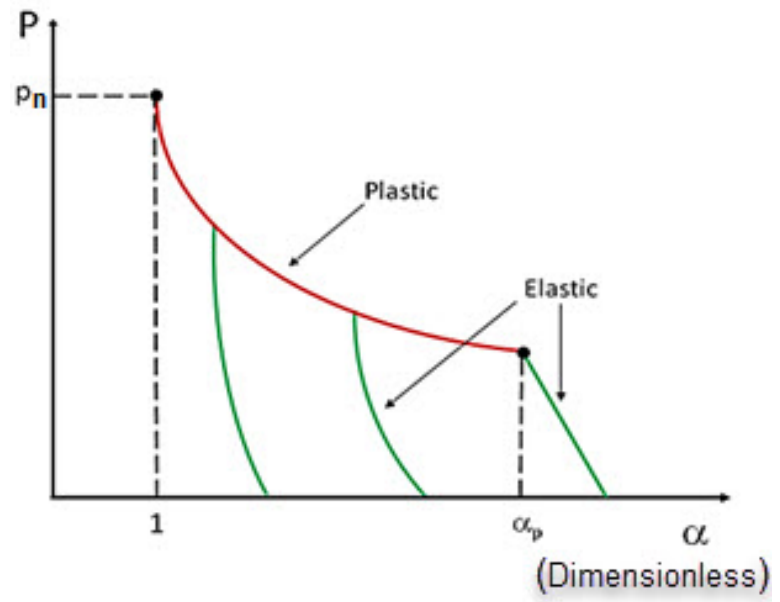

Figure 14: alpha equation of state for the Behavior of the material. 
Carroll and Holt [31] equation of state the modified mode as follows:

$$
\mathrm{P}=\left(\frac{1}{\alpha}\right) f\left(\frac{v}{\alpha}, e\right)
$$

\section{Crushable Foam Strength Model}

The Foam Crushable model is a relatively simple model for modeling the behaviour of porous materials such as foam, as shown in Fig. 15 of its strength. The main stress is related to the volume pressure. Unloading and reloading by EOS are usually linear. The manufacturing failure criteria are part of the model and have a maximum tensile limit [32-36]. Foam materials are modeled with the homogeneous elastic model in Ansys, which is obtained by testing the linear equation of state and the Foam Crushable strength model in Autodyn and the data related to this model from the material pressure test. To use this model, the software strength only allows the user to use the linear model equation [36-40].

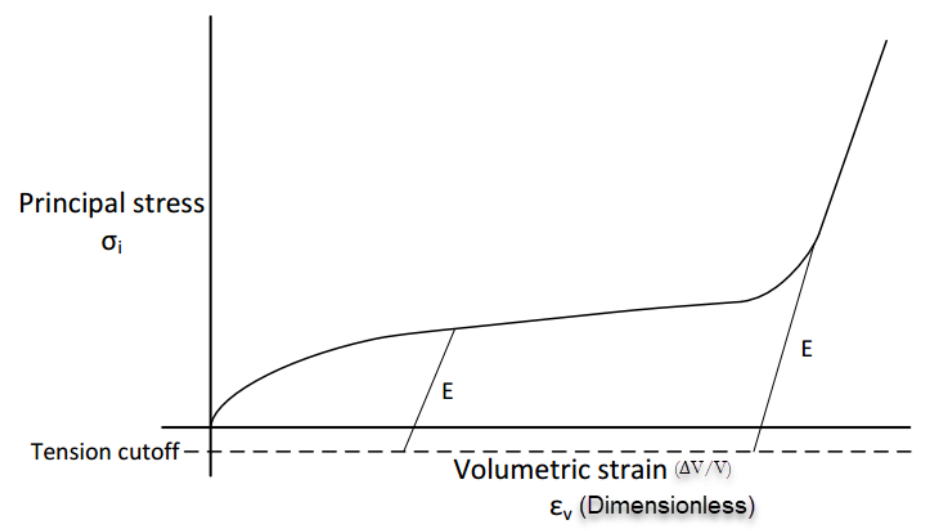

Figure 15: Foam Crushable strength model [35].

Using this model, the following table data is required in addition to the compression diagram.

\begin{tabular}{lc}
\hline \multicolumn{1}{c}{ Parameter } & Relation \\
Density $\left(\mathrm{g} / \mathrm{cm}^{3}\right)$ & $\mathrm{P}=\frac{m}{v}$ \\
Bulk Modulus $(\mathrm{MPa})$ & $K=-V \frac{d p}{d v}$ \\
Shear Modulus $(\mathrm{MPa})$ & $G=\frac{E}{2(1-v)}$ \\
Max Tensile Stress $(\mathrm{MPa})$ & - \\
\hline
\end{tabular}

Table 2: Parameters of the crushable foam model.

\section{NUMERICAL SIMULATION}

$\mathrm{B}$

ecause the geometry and loading of the problem have axial symmetry, there is no need to model the model in three dimensions, and only a part of the problem is modeled in two dimensions. Fig. 16 shows the two-dimensional geometry modeled in Autodyn software.

The equation of state, the equation of strength, and the equation of failure are necessary to simulate any material in Autodyn, the equations used in the table are reported.

To measure parameters such as the velocity and pressure of the blast wave in the air from the Eulerian gauges and to measure the deformation of the specimen, etc. in Fig. 17, the dimensions of the shock tube and the coordinates of the explosion charge are shown. 
In the software for air as a filler, conditions such as internal energy and density must be defined, which are shown in Tab. 3 of the values of parameters.

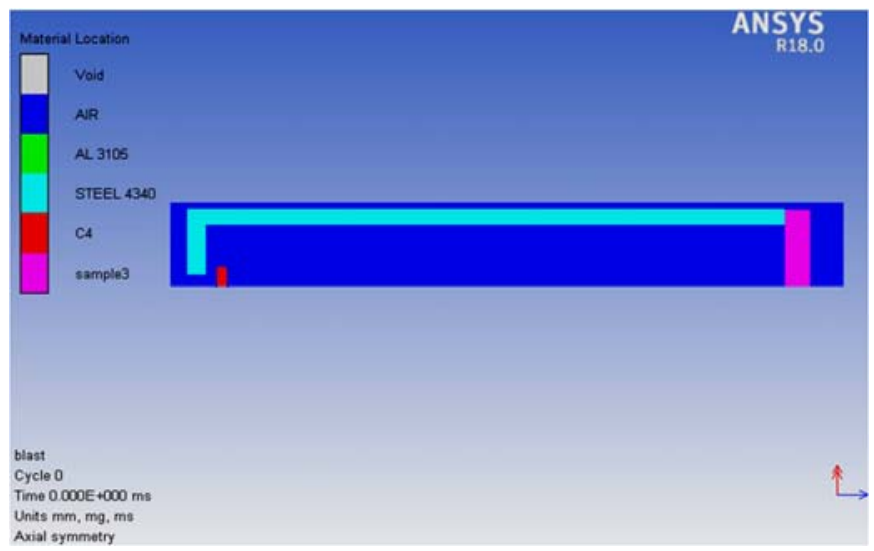

Figure 16: Two-dimensional geometry.

\begin{tabular}{cccc}
\hline Materials & EOS & Failure model & Strength model \\
Aluminum & Shock & Johnson-Cook & Johnson-Cook \\
Al foam & Crushable Foam & - & Linear \\
C4 & JWL & - & - \\
Air & Ideal gas & - & - \\
\hline
\end{tabular}

Table 3: Equations used in modeling.

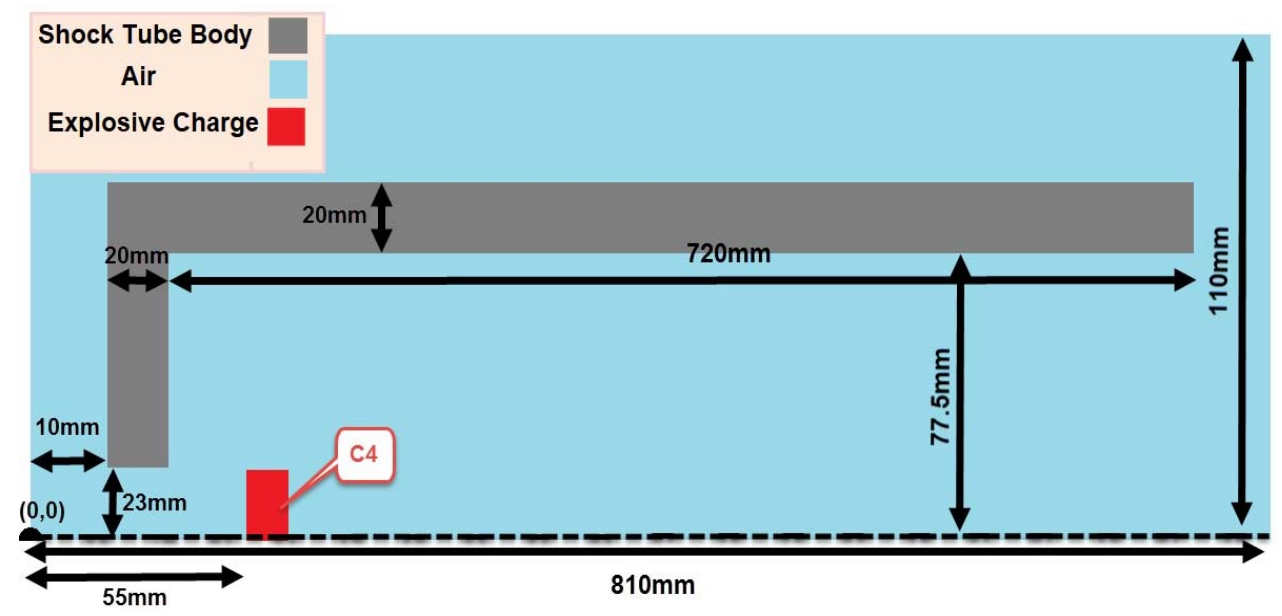

Figure 17: Shock tube dimensions and explosive charge placement coordinates.

\begin{tabular}{cc}
\hline Name & Initial \\
Material & AIR \\
Density & $1.23 \mathrm{E}-3\left(\mathrm{~g} / \mathrm{cm}^{3}\right)$ \\
Internal Energy & $206.8 \mathrm{~J}$ \\
Shell Thickness & $0.00 \mathrm{E}+00$ \\
X Velocity & $0.00 \mathrm{E}+00$ \\
Y Velocity & $0.00 \mathrm{E}+00$ \\
\hline
\end{tabular}

Table 3: Initial condition for air as a Euler filler. 
Defining boundary conditions is a prerequisite for any problem, for conditions involving supports and for assuming infinite space around the boundary condition Flow out (Euler) this prevents the reflection of the wave after colliding with the modeling boundaries of the problem, both of which are shown in Tab. 4 and the mechanical properties of aluminum alloy AA3105 show in Tab. 5.

\begin{tabular}{cc}
\hline Type & Flow out (Euler) \\
Coordinate System & 0 \\
Preferred Material & ALL EQUAL \\
GYPE & $\begin{array}{c}\text { General 2D } \\
\text { Velocity }\end{array}$ \\
Coordinate System & 0 \\
Constant X-Velocity & $0.00000 \mathrm{E}+00$ \\
Constant Y-Velocity & $0.00000 \mathrm{E}+00$ \\
\hline
\end{tabular}

Table 4: Model boundary conditions.

\begin{tabular}{cccccc}
\hline Density & Poisson's Ratio & Elastic Module & Shear Strength & Yield Stress & Elongation \\
$2.6-2.8 \mathrm{~g} / \mathrm{cm}^{3}$ & 0.33 & $70-80 \mathrm{MPa}$ & $97 \mathrm{MPa}$ & $130 \mathrm{MPa}$ & $7 \%$ \\
\hline
\end{tabular}

Table 5: The mechanical properties of aluminum alloy AA3105 [33].

For this sheet, according to the article, Johnson Cook's failure model is used, and the coefficients of this model for aluminum 3105 are shown in Tab. 6.

\begin{tabular}{ccccc}
\hline $\mathrm{A}(\mathrm{MPa})$ & $\mathrm{B}(\mathrm{MPa})$ & $\mathrm{C}$ & $\mathrm{n}$ & $\mathrm{m}$ \\
130 & 465 & 0.015 & 0.34 & 0.001 \\
\hline
\end{tabular}

Table 6: Johnson's Cook Failure Model Coefficients for Aluminum [33].

An independent study of mesh is one of the main parts of numerical work. The mesh size is reduced in a few steps so that the answer (for example, the sheet center displacement) is slightly different from the previous solution and the mesh size of the previous step is considered as the optimal mesh and the rest of the numerical studies are done using this size. In this study, independent of the mesh for air and aluminum casting panel with mineral pumice particles is considered as a material. In the following, the simulations of $5 \mathrm{~g}$ of $\mathrm{C} 4$ and sheet with a thickness of $2 \mathrm{~mm}$ and a core with a thickness of $15 \mathrm{~mm}$ are each investigated and considered separately.

\begin{tabular}{ccccc}
\hline Mesh Size $(\mathrm{mm})$ & 3 & 2 & 1 & 0.5 \\
$\begin{array}{c}\text { Overpressure }(\mathrm{kPa}) \text { at } \\
\text { first tube after sheet }\end{array}$ & 2700 & 2900 & 3000 & 3050 \\
\hline
\end{tabular}

Table 7: Non-dependence on air mesh.

\begin{tabular}{cccccc}
\hline $\begin{array}{c}\text { Mesh Size }(\mathrm{mm}) \\
\begin{array}{c}\text { The sheet center } \\
\text { displacement }(\mathrm{mm})\end{array}\end{array}$ & 3 & 2 & 1 & 0.5 & 0.25 \\
\hline
\end{tabular}

Table 8: Non-dependence on aluminum sheet mesh. 


\begin{tabular}{cllll}
\hline $\begin{array}{c}\text { Mesh Size }(\mathrm{mm}) \\
\begin{array}{c}\text { The specimen center displacement } \\
(\mathrm{mm})\end{array}\end{array}$ & 3 & 2 & 1 & 0.5 \\
\hline
\end{tabular}

Table 8: Non-dependence on core sample mesh.

Therefore, the mesh size of $1 \mathrm{~mm}$ for air and $0.5 \mathrm{~mm}$ for aluminum sheet was selected as the optimal mesh, and the parameters were compared with the article [17], which is shown in Fig. 18 of the specimen's center displacement and Fig. 19 Shows shock wave diagram due to different charges in the center of the sheet.

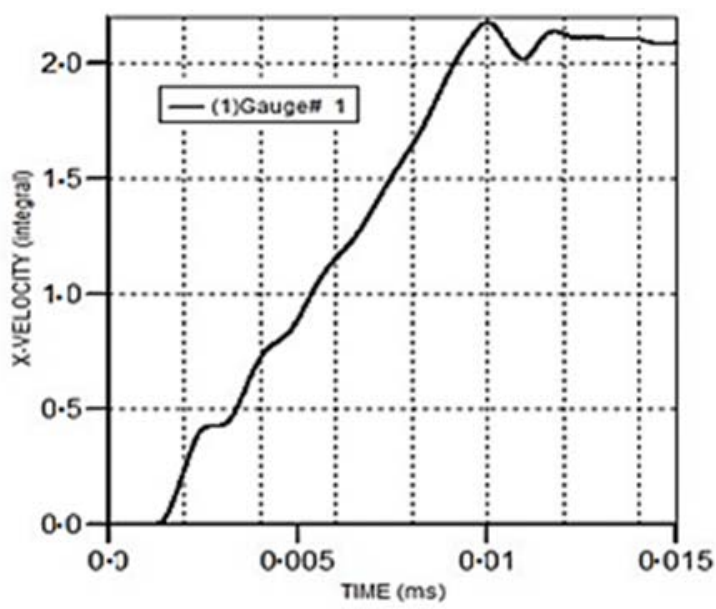

First Specimen

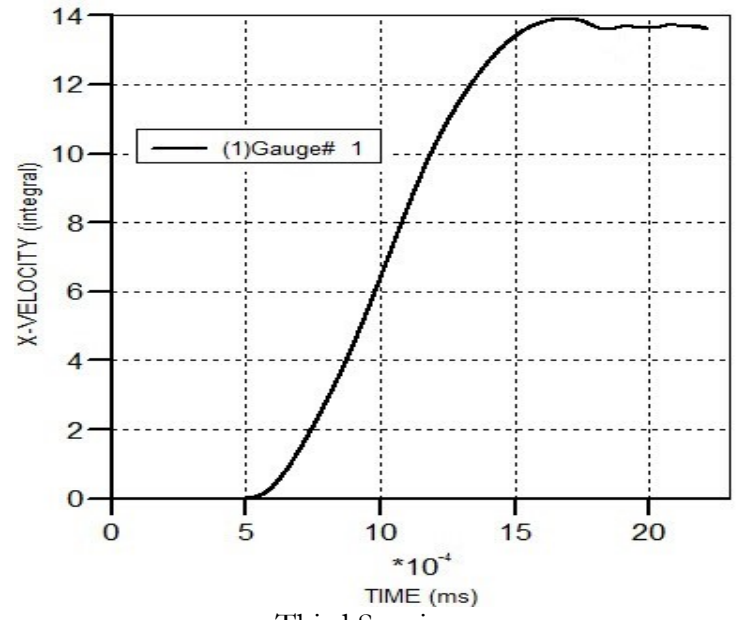

Third Specimen

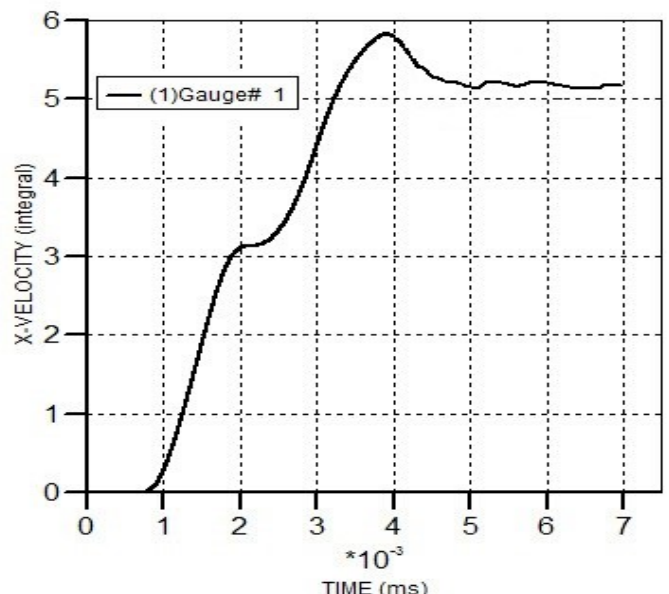

Second Specimen

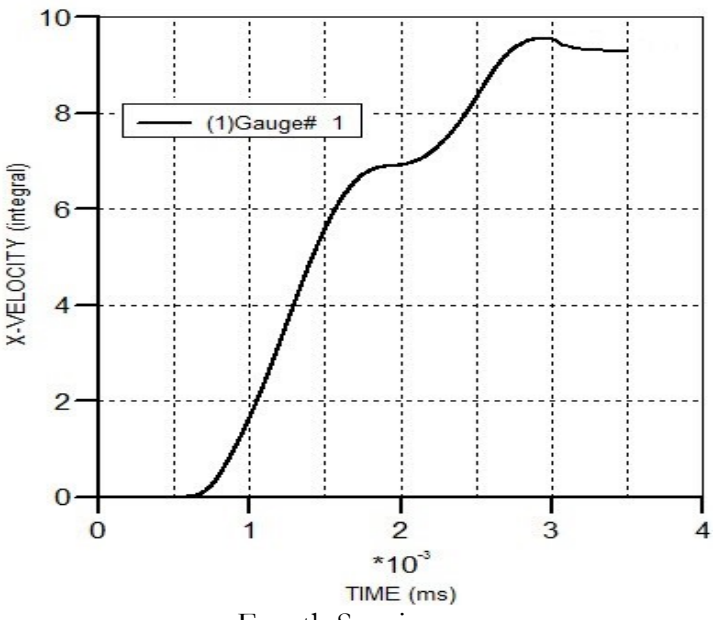

Fourth Specimen

Figure 18: Diagram of the specimen's center displacement.

Evaluation and accuracy, the simulation results of the crushable foam method are compared with the same article [17], which shows Fig. 20 of the problem geometry used in the article. The target plate is a sandwich with an aluminum foam core and AISI304 steel shell with three different thicknesses that have fixed supports. The cylindrical projectile is made of Alporas aluminum foam (a type of aluminum foam closed-cell foam) that hits the target at a velocity of 160 to $570 \mathrm{~m} / \mathrm{s}$ and the rate of deformation of the specimens is measured. Fig. 21 shows the aluminum foam strain-stress diagram and steel sheet used in the article [17].

The approximate density of the foam core used is about $\varrho_{c}=430 \mathrm{~kg} / \mathrm{m}^{3}$, and for testing in the paper, two thicknesses of 10 and $22 \mathrm{~mm}$ were used, the covering thickness of which was 1.18 and $0.88 \mathrm{~mm}$, respectively. The projectile has an approximate length of $l_{0}=50 \mathrm{~mm}$ and a diameter of $\mathrm{d}=48.5 \mathrm{~mm}$ of Alporas foam with an approximate density between 380 and $490 \mathrm{~kg} / \mathrm{m}^{3}$. The projectile is fired by a gas gun with a length of $4.5 \mathrm{~m}$ and 
a velocity of 160 to $570 \mathrm{~m} / \mathrm{s}$. Tab. 11 compares the results of the simulation of the crushable foam method and experimental test in Autodyn with the reference article [17].
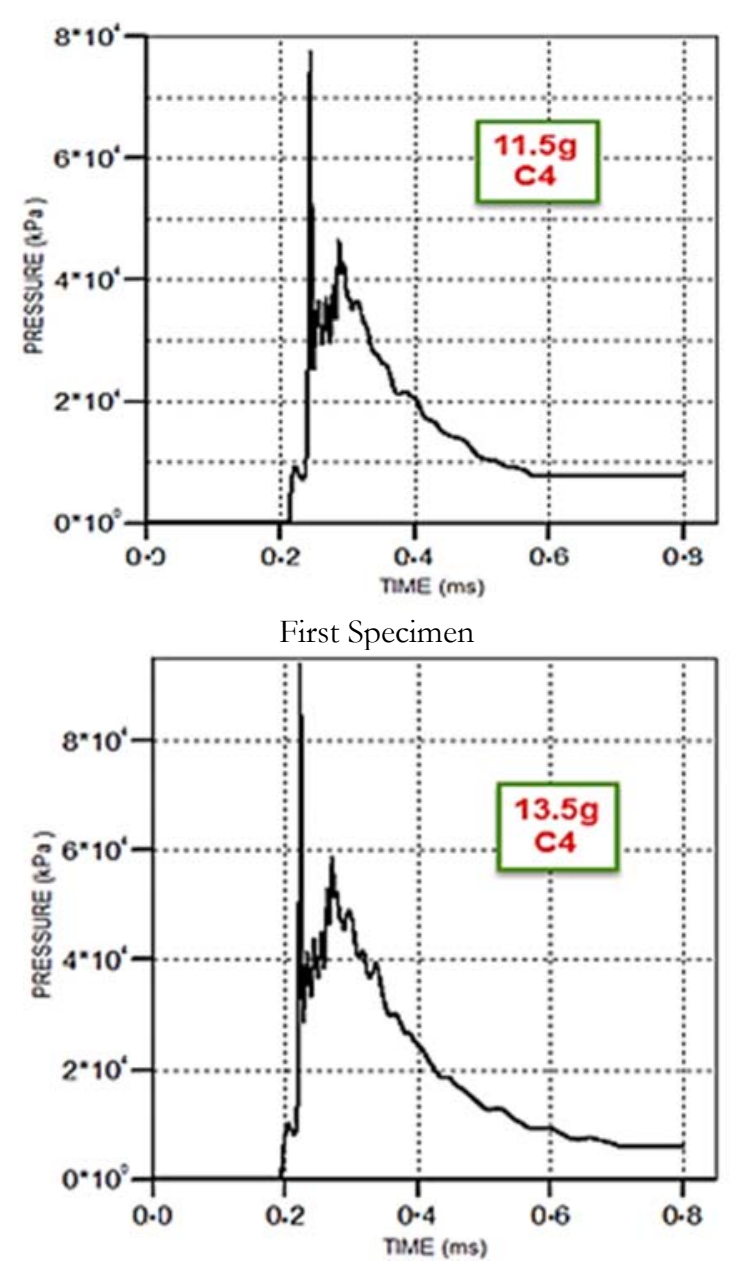

Third Specimen

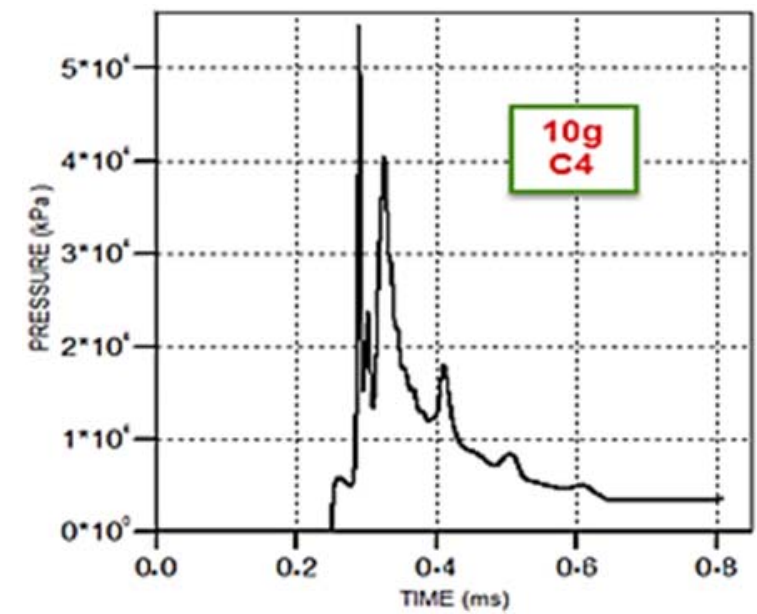

Second Specimen

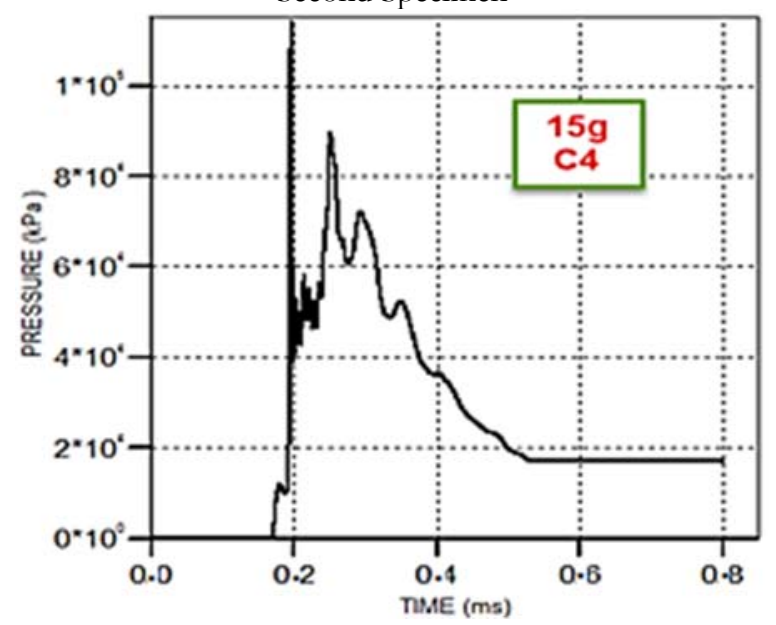

Fourth Specimen

Figure 19: Shock wave diagram in the center of the sheet.

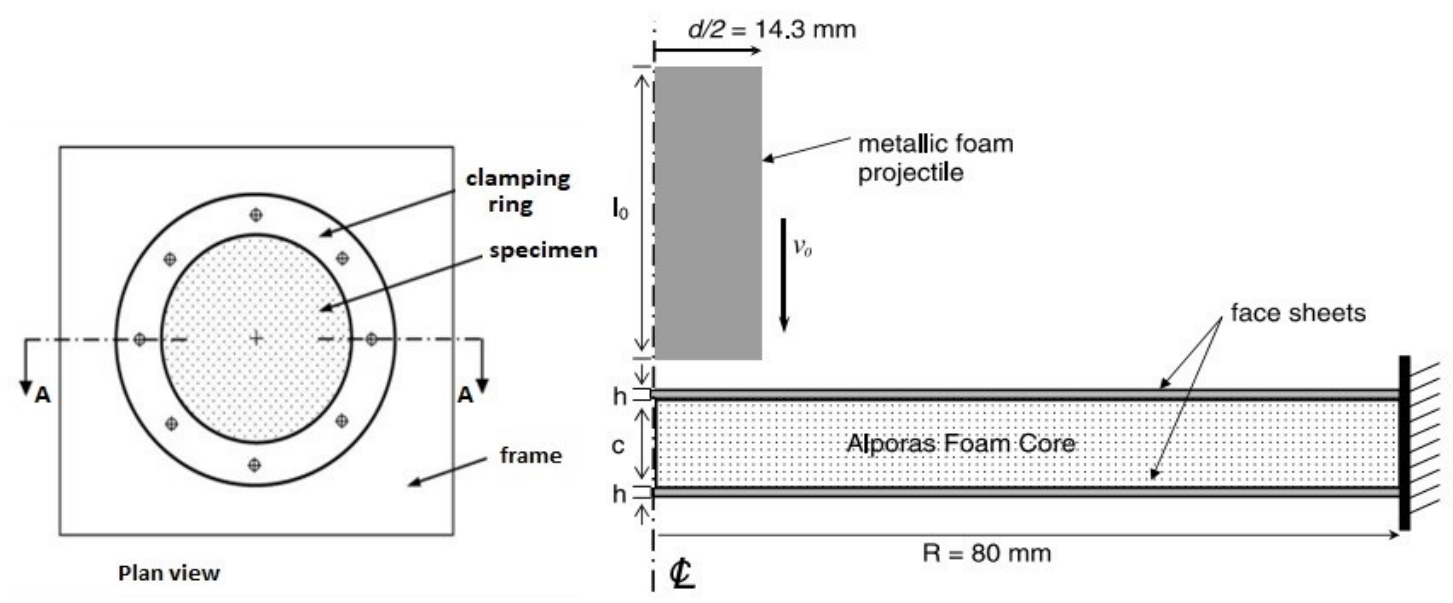

Figure 20: The problem geometry. 

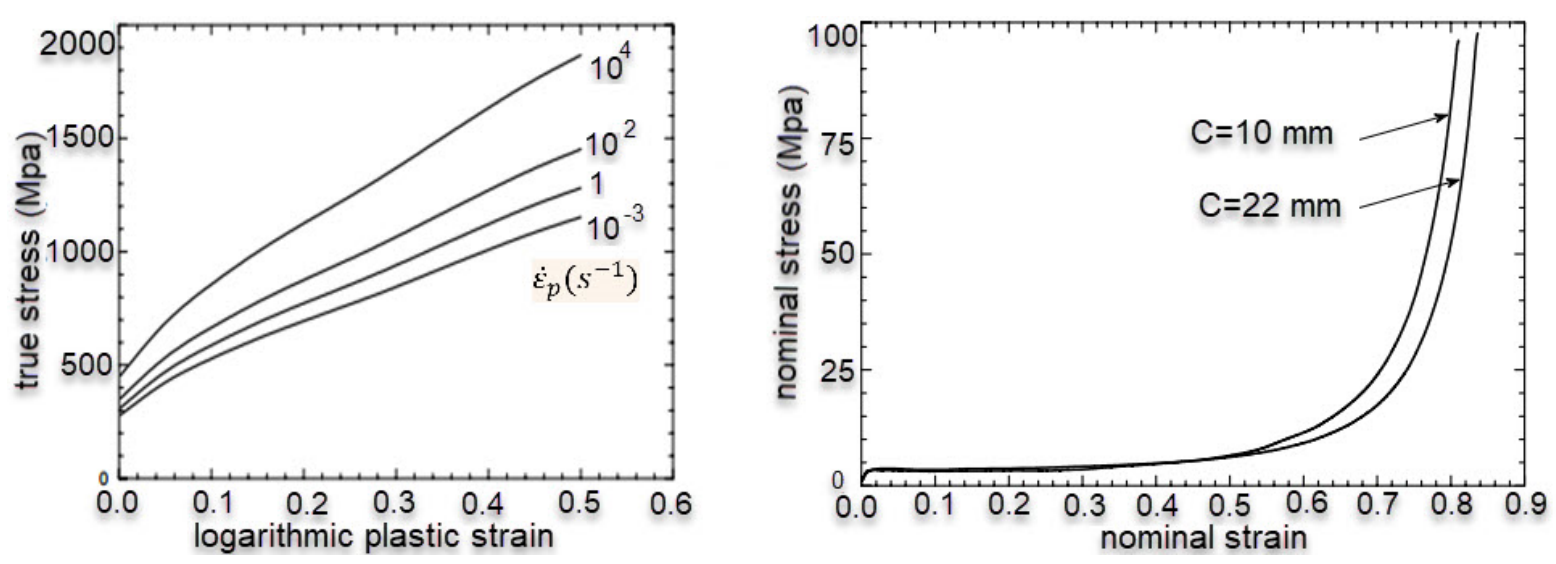

Figure 21: Stress-strain diagram.

\begin{tabular}{cccccc}
\hline- & Density & Young modulus & Poisson ratio & Yield stress & $\begin{array}{c}\text { Tangent } \\
\text { modulus }\end{array}$ \\
Alporas foam Target & $185 \mathrm{~kg} / \mathrm{m}^{3}$ & $30 \mathrm{MPa}$ & 0.29 & $0.25 \mathrm{MPa}$ & $0.64 \mathrm{MPa}$ \\
\hline
\end{tabular}

Table 9: Properties of Alporas foam.

\begin{tabular}{cccccc}
\hline Density & $\begin{array}{c}\text { Elastic } \\
\text { modulus }\end{array}$ & Poisson ratio & Yield strength & Shear modulus \\
Stainless steel 304 & $8000 \mathrm{~kg} / \mathrm{m}^{3}$ & $193 \mathrm{MPa}$ & 0.29 & $205 \mathrm{MPa}$ & $86 \mathrm{GPa}$ \\
\hline
\end{tabular}

Table 10: Properties of stainless steel 304.

\begin{tabular}{ccccccc}
\hline $\mathrm{C}(\mathrm{mm})$ & $\mathrm{P}_{\mathrm{p}}\left(\mathrm{kN} / \mathrm{m}^{2}\right)$ & $\mathrm{l}_{0}(\mathrm{~mm})$ & $\mathrm{V}_{0}(\mathrm{~m} / \mathrm{s})$ & $\begin{array}{c}\text { In the } \\
\text { Article } \\
{[17](\mathrm{mm})}\end{array}$ & $\begin{array}{c}\text { Research } \\
\text { study } \\
(\mathrm{mm})\end{array}$ & Error $(\%)$ \\
10 & 433 & 47 & 160 & 2.0 & 2.4 & $20 \%$ \\
10 & 388 & 50 & 321 & 4.4 & 5.1 & $15 \%$ \\
10 & 509 & 45 & 434 & 8.1 & 9.4 & $16 \%$ \\
10 & 503 & 48 & 551 & 12.8 & 14 & $9 \%$ \\
22 & 393 & 51 & 157 & 1.1 & 1.3 & $18 \%$ \\
22 & 487 & 48 & 265 & 3.1 & 3.7 & $19 \%$ \\
22 & 490 & 47 & 414 & 5.7 & 6.7 & 11 \\
\hline
\end{tabular}

Table 11: Comparison of experimental and simulation results. 


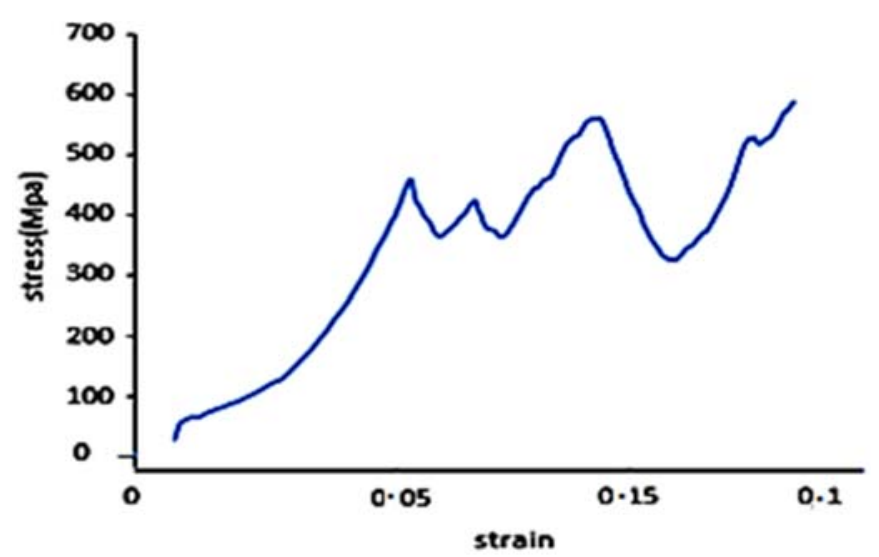

A) Mineral Pumice

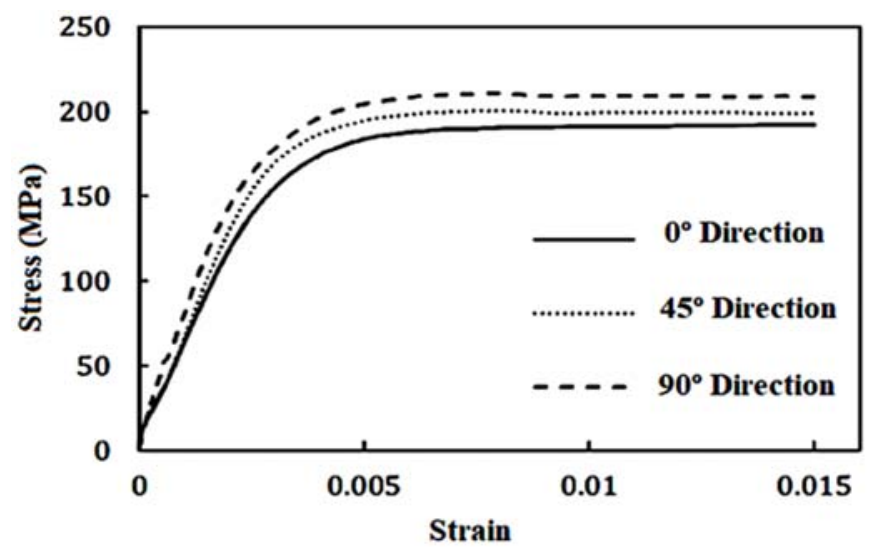

B) Aluminum AA3105 [33].

Figure 22: Stress-strain diagram.

\section{Panel Optimization}

$\mathrm{O}$ ne of the goals of the Design of the Experiment is to be able to observe and identify output changes with conscious changes in process input variables. There are several ways to design a test. One of the first methods in this field was the factorial method. The number of experiments is obtained by the relation $\mathrm{N}=\mathrm{Lm}$. In this article, the optimal Taguchi method is used.

\section{Multi-objective optimization by Response Surface method}

The response surface methodology is a collection of mathematical and statistical techniques to match the experimental data with polynomial models. the response surface method is presented as one of the experimental modeling methods. the response surface method is one of the approaches in the design of experiments and sciences. In the response surface method, the solution is tried to find a way to estimate the second-order effects and even the local form of the response surface. in this study, specific goals are pursued seriously, which can be used to improve the process by finding optimal inputs, removing the problems and weaknesses of the process, and stabilization of it. here, stabilization is an important concept in quality statistics which indicates minimize the effects of secondary variables or friction [42].

Benefits of the RSM method:

* It analyses and analyses the interaction between parameters.

* quadratic models can be used to analyses properties and optimization.

* in this method statistical method is determined by interpolation between input variables, optimal values.

- (RSM) the method receives qualitative variables and is used in the analysis and optimization of properties. 
To investigate the ability of these relations to predict the response in Fig. 24, the diagram of real values versus the predicted values is given. This diagram shows the values of the predicted response to real values to help identify these values or a group of values that are not predicted by the model. Fig. 25 shows the normal residual diagram is shown, which shows the normal probability graph, and the residues follow a normal distribution. Even with natural data, there are expectations of some intermediate distributions. The Perturbation diagram is a specimen of pea pumice in Fig. 26. Comparing the effect of all parameters at a particular point in the design space makes it possible. The reference point is located at the midpoint of all factors marked with a zero code. The slope or curvature of a parameter indicates that the response is sensitive to this parameter. The relatively smooth line shows the insensitivity of the response to changes in that particular factor. In this diagram, the effect on interactions is not visible. Due to the almost identical slope of the two parameters, they have almost the same effect on the response, and the effect of sample thickness is slightly less than the mass of the explosive charge. Fig. 27 shows the Cox box diagram, which is a tool to help identify the most appropriate power transfer function to apply to the response. The lowest point in the diagram shows the best value of Lambda, in which at least the sum of the remaining squares in the converted model is shown. When the maximum ratio to the minimum response value is greater than three, there will be a greater ability to improve the model using the power function. This diagram also shows the $95 \%$ confidence range. Fig. 28 shows the three-dimensional graph for pea pumice and Fig. 29 shows the displacement changes by changing the explosion charge for pea pumice and Fig. 30 shows the three-dimensional graph for almond pumice and Fig. 31 shows the displacement changes by changing the explosion charge for almond pumice.

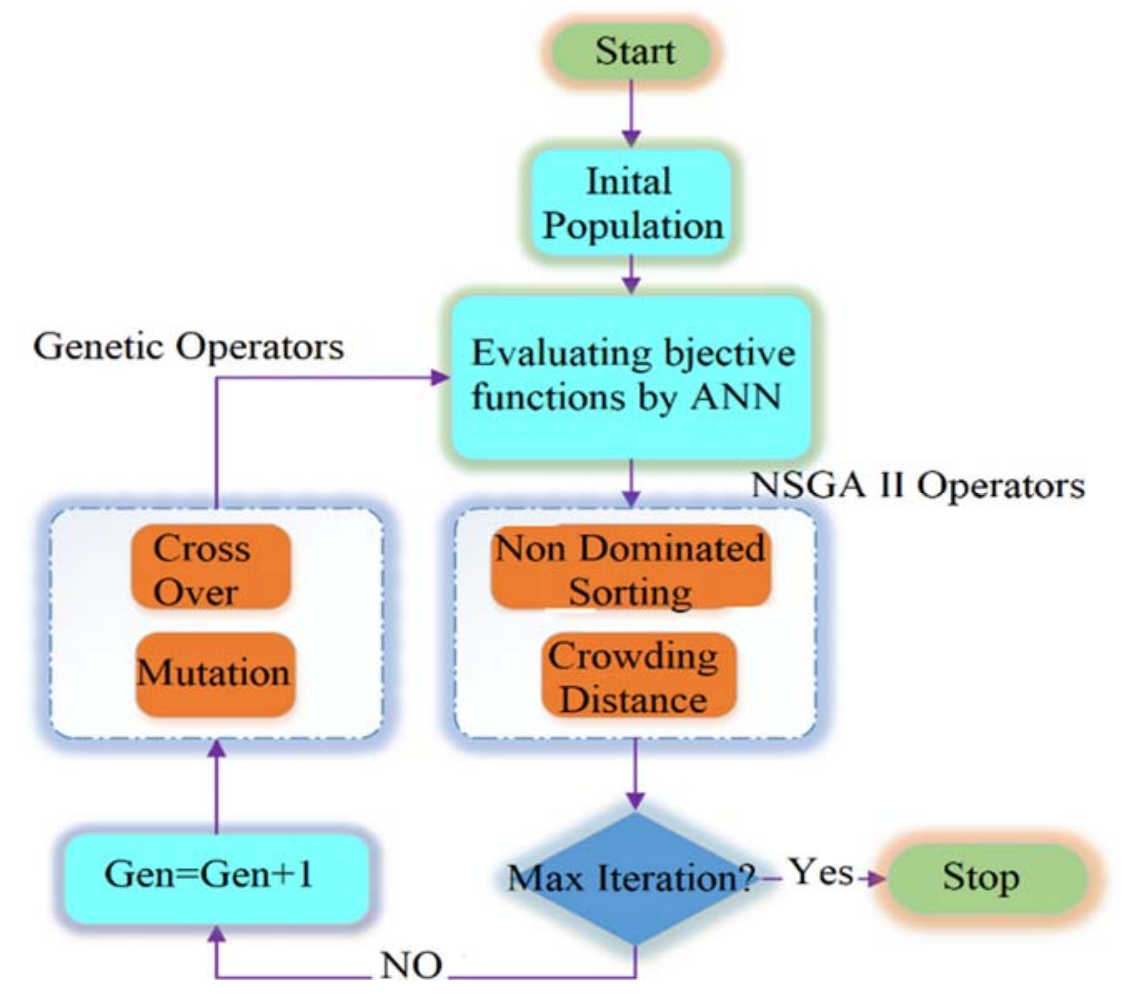

Figure 23: Optimization flowchart.

\begin{tabular}{ccccc}
\hline- & A & B & C & D \\
$\begin{array}{c}\text { Specimens } \\
\text { thickness (mm) }\end{array}$ & 45 & 36.5 & 28.5 & 20 \\
$\begin{array}{c}\text { Explosive charge } \\
\text { C4 (g) }\end{array}$ & 15 & 13.5 & 11.5 & 10 \\
\hline
\end{tabular}

Table 12: The values for numerical factors. 


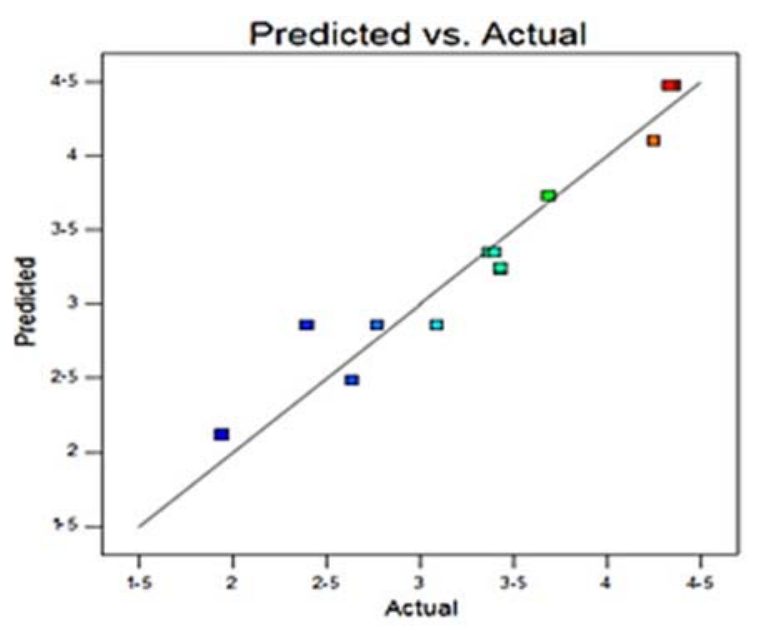

Figure 24: Real values versus predicted values.

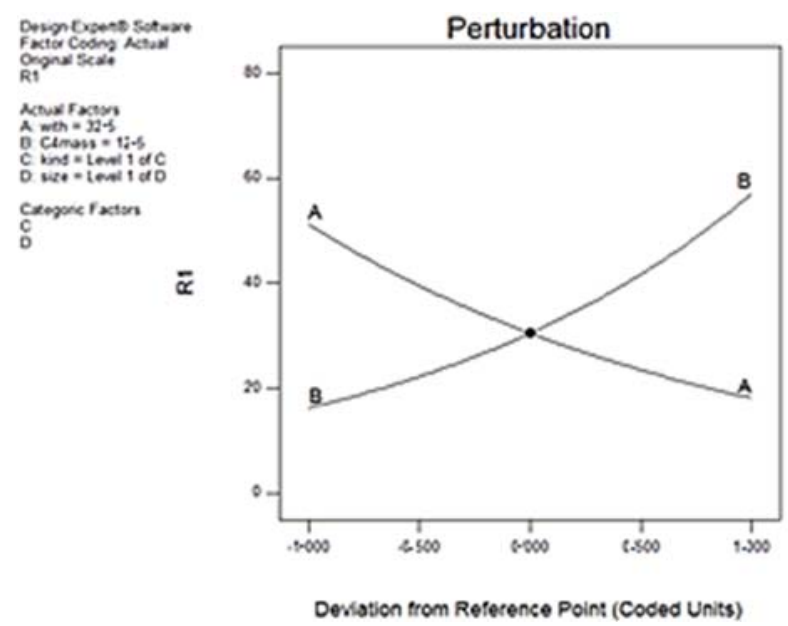

Figure 26: Perturbation diagram for pea specimen.

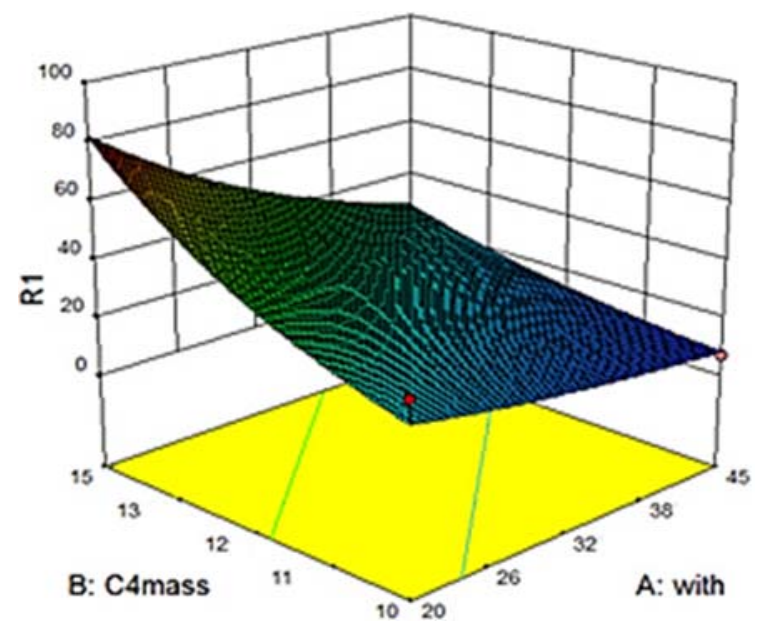

Figure 28: 3D graph for pea pumice.

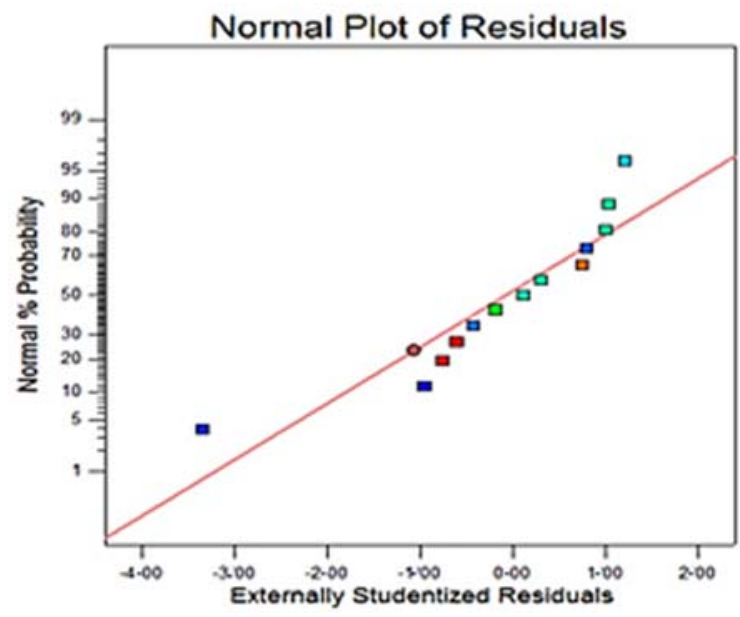

Figure 25: Normal residual diagram.

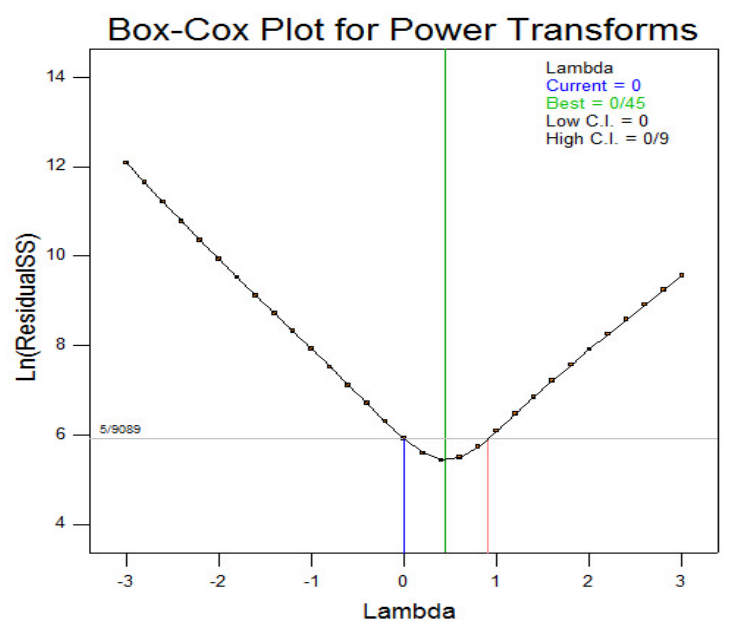

Figure 27: Cox Box Curve.

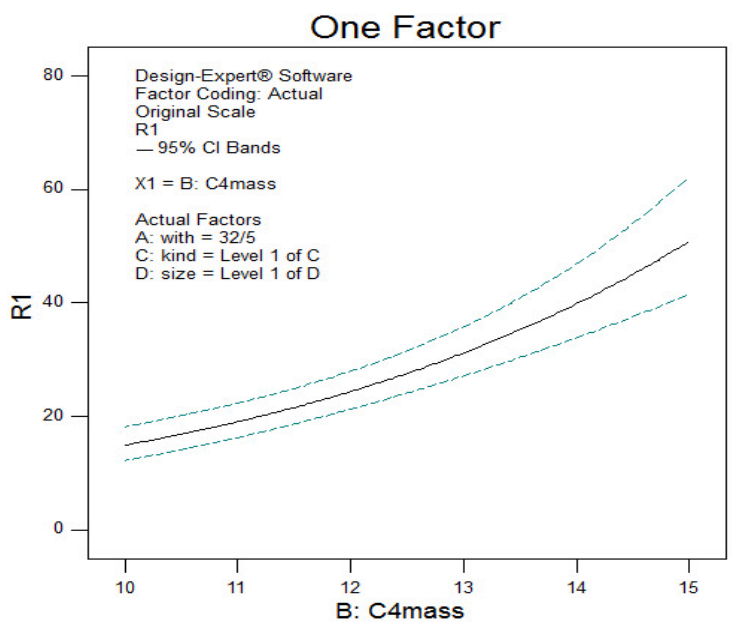

Figure 29: Displacement changes by changing the explosion charge for pea pumice. 


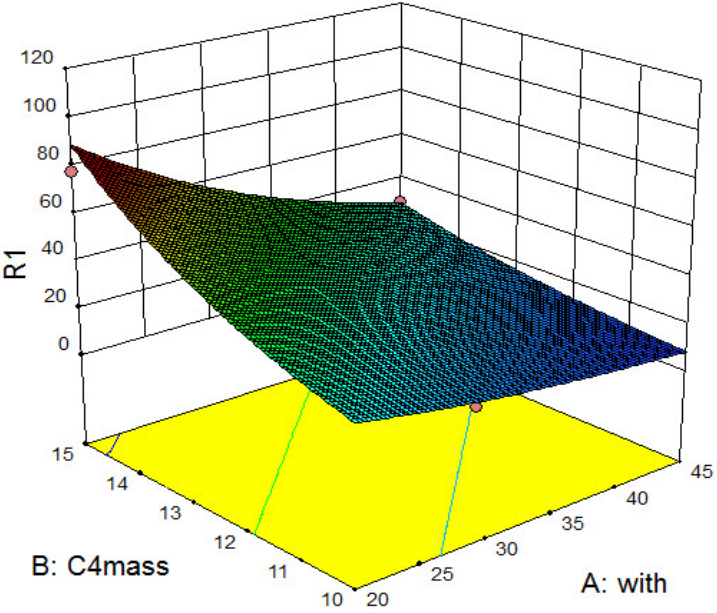

Figure 30: 3D graph for almond pumice.

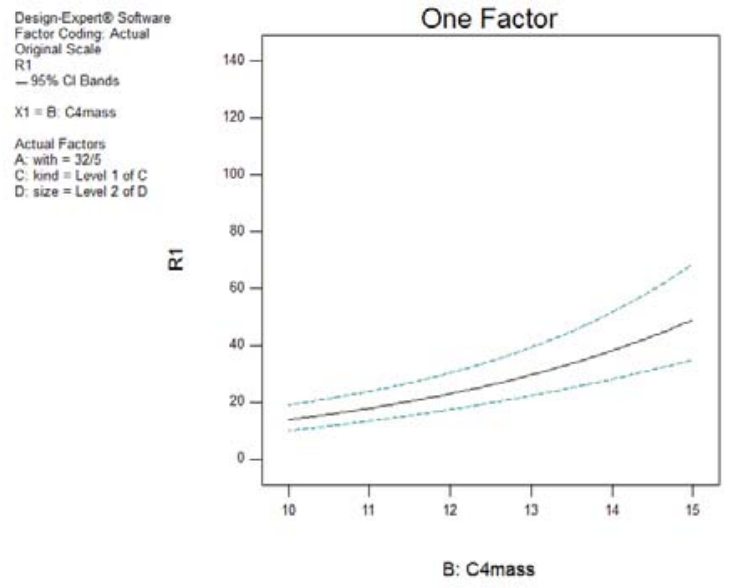

Figure 31: Displacement changes by changing the blast charge for almond pumice.

\begin{tabular}{cccccc}
\hline Row & Before & Mass C4 & Size & Response & Satisfaction \\
1 & 25.28 & 13.26 & Almond & 42.79 & 0.634 \\
2 & 25.19 & 13.26 & Almond & 42.91 & 0.634 \\
3 & 25.53 & 13.21 & Almond & 43.05 & 0.627 \\
4 & 26.69 & 13.02 & Pea & 44.25 & 0.595 \\
5 & 26.83 & 13.04 & Pea & 44.15 & 0.595 \\
6 & 26.95 & 12.98 & Pea & 44.53 & 0.588 \\
\hline
\end{tabular}

Table 13: The values of the optimized points in the experimental test.

\begin{tabular}{ccccc}
\hline Test number & $\begin{array}{c}\text { The type of } \\
\text { pumice }\end{array}$ & Pumice sizes & $\begin{array}{c}\text { Explosive } \\
\text { forming C4 (g) }\end{array}$ & $\begin{array}{c}\text { Specimen } \\
\text { Thickness } \\
(\mathrm{mm})\end{array}$ \\
\hline 1 & Brown & Peas & 10 & 28.5 \\
3 & Black & Almond & 15 & 20 \\
4 & Brown & Peas & 15 & 45 \\
5 & Black & Almond & 15 & 45 \\
6 & Black & Almond & 10 & 28.5 \\
7 & Black & Almond & 10 & 28.5 \\
8 & Brown & Almond & 10 & 45 \\
9 & Brown & Peas & 15 & 20 \\
10 & Black & Peas & 11.5 & 45 \\
11 & Black & Peas & 13.5 & 20 \\
12 & Black & Peas & 11.5 & 28.5 \\
13 & Brown & Almond & 15 & 36.5 \\
\hline
\end{tabular}

Table 14: Suggested experiments response surface methodology. 


\section{CONCLUSION}

I $\mathrm{n}$ this paper, using numerical simulation in Autodyn software and experimental testing of aluminum with mineral pumice particles were obtained. This structure, which is obtained by casting aluminum on mineral pumice particles, is subjected to static loading and shock load and is compared with the behaviour of aluminum foam.

the results of the experiments and numerical simulation were compared and there was a good agreement between these two modes of investigations, indicating the validity and accuracy of simulation assumptions.

1) One of the main results of this study is to approximate the properties of the specimen in static loading and impact with aluminum foam, so use this material in some applications of aluminum foam that is not economically justified.

2) The two types of pumice used in this study had good results against static loading and explosive loading in experimental testing.

3) Considering the specimen thickness parameter and the explosion charge mass, the results show that the impact charge of the specimen is slightly higher than the specimen thickness.

4) Relations, to determine the objective function (displacement of the specimen center) in the range specified for the parameters, have been obtained and presented by Design-Expert software using the response surface method.

5) Optimal thickness values for explosive consumption of $13 \mathrm{~g}$ about $25 \mathrm{~mm}$ have been obtained by Design-Expert software.

The ability of this material as sound and heat insulation can be investigated in the future because it is one of the applications of aluminum foam as sound and heat insulation in the construction industry.

\section{ACKNOWLEDGMENTS}

$\mathrm{W}$

e thank the Imam Hussein University Laboratory for conducting a research test.

\section{REFERENCES}

[1] Deno, N. C., Richey, H. G., Liu, J. S. and Lincoln, D. N. (1965). Sucrose Synthesis, J. Am. Chem. Soc. 87(3), pp.45334538.

[2] Zenkert, D. (1995). An introduction to sandwich construction. Engineering materials advisory services.

[3] Evans, A. G., Hutchinson, J. W. and Ashby, M. F. (1998). Multifunctionality of cellular metal systems. Progress in materials science, 43(3), pp. 171-221. DOI: 10.1016/S0079-6425(98)00004-8.

[4] Nemat-Nasser, S., Kang, W. J., McGee, J. D., Guo, W. G. and Isaacs, J. B. (2007). Experimental investigation of energyabsorption characteristics of components of sandwich structures. International journal of impact engineering, 34(6), pp. 1119-1146. DOI: 10.1016/j.ijimpeng.2006.05.007.

[5] Cernak, I. (2010). The importance of systemic response in the pathobiology of blast-induced neurotrauma. Frontiers in neurology, 1, 151. http://doi.org/10.3389/fneur.2010.00151.

[6] Ribeiro, D. T. D. C. (2011). Estudo da viabilidade técnica do processo de fabricação de espumas metálicas por reciclagem de cavacos da liga AA356. http://repositorio.unicamp.br/handle/REPOSIP/263567.

[7] Rahmani, M., Oskouei, A. N. and Petrudi, A. M. (2020). Experimental and Numerical Study of the Blast Wave Decrease using Sandwich Panel by Granular Materials Core. Defence Technology. DOI: 10.1016/j.dt.2020.09.004.

[8] Hanssen, A. G., Enstock, L. and Langseth, M. (2002). Close-range blast loading of aluminium foam panels. International Journal of Impact Engineering, 27(6), pp. 593-618. DOI: 10.1016/S0734-743X (01)00155-5.

[9] Lopatnikov, S. L., Gama, B. A., Haque, M. J., Krauthauser, C., Gillespie Jr, J. W., Guden, M. and Hall, I. W. (2003). Dynamics of metal foam deformation during Taylor cylinder-Hopkinson bar impact experiment. Composite Structures, 61(1-2), pp. 61-71. DOI: 10.1016/S0263-8223(03)00039-4.

[10] Irie, S., Greg, K., Ren, Z. and Itoh, S. (2016). Dynamic property of aluminum foam. The International Journal of Multiphysics, 4(2). DOI: 10.1260/1750-9548.5.3.243. 
[11] Hangai, Y., Kato, H., Utsunomiya, T., Kitahara, S., Kuwazuru, O. and Yoshikawa, N. (2012). Effects of porosity and pore structure on compression properties of blowing-agent-free aluminum foams fabricated from aluminum alloy die castings. Materials Transactions, 53(8), pp. 1515-1520. DOI: 10.2320/matertrans.M2012125.

[12] Shim, C., Yun, N., Yu, R. and Byun, D. (2012). Mitigation of blast effects on protective structures by aluminum foam panels. Metals, 2(2), pp. 170-177. DOI: 10.3390/met2020170.

[13] Vesenjak, M., Borovinšek, M., Ren, Z., Irie, S. and Itoh, S. (2012). Behavior of Metallic Foam under shock wave loading. Metals, 2(3), 258-264. DOI: 10.3390/met2030258

[14] Mahmoud, M., Farag, H. and Mahfouz, S. (2015). Behavior of Reinforced Concrete Slab with Aluminum Foam Panels Subjected to Blast Loadings. In International Conference on Aerospace Sciences and Aviation Technology 16, ASAT16, pp. 1-11. DOI: $10.21608 /$ asat.2015.23035.

[15] Goel, M. D., Altenhofer, P., Matsagar, V. A., Gupta, A. K., Mundt, C. and Marburg, S. (2015). Interaction of a shock wave with a closed cell aluminum metal foam. Combustion, Explosion and Shock Waves, 51(3), 373-380. DOI: 10.1134/S0010508215030144.

[16] Barthélémy, R., Jacques, N., Vermeersch, F. and Kerampran, S. (2015). A constitutive model for the compressive response of metallic closed-cell foams including micro-inertia effects. In EPJ Web of Conferences, 94, p. 04014. DOI: 10.1051 /epjconf/20159404014.

[17] Radford, D. D., McShane, G. J., Deshpande, V. S. and Fleck, N. A. (2006). The response of clamped sandwich plates with metallic foam cores to simulated blast loading. International Journal of solids and structures, 43(7-8), pp. 22432259. DOI: $10.1016 /$ j.ijsolstr.2005.07.006.

[18] Su, L., Liu, H., Yao, G. and Zhang, J. (2019). Experimental study on the closed-cell aluminum foam shock absorption layer of a high-speed railway tunnel. Soil Dynamics and Earthquake Engineering, 119, pp. 331-345. DOI: 10.1016/j.soildyn.2019.01.012.

[19] Taherkhani, B., Kadkhodapour, J., Anaraki, A. P., Saeed, M. and Tu, H. (2020). Drop Impact of Closed-Cell Aluminum Foam: Experiment and Simulation. Journal of Failure Analysis and Prevention, pp. 1-6. DOI: 10.1007/s11668-02000843-8.

[20] Hedayati, R., Ahmadi, S. M., Lietaert, K., Pouran, B., Li, Y., Weinans, H. and Zadpoor, A. A. (2018). Isolated and modulated effects of topology and material type on the mechanical properties of additively manufactured porous biomaterials. Journal of the mechanical behavior of biomedical materials, 79, pp. 254-263.

DOI: $10.1016 /$ i.jmbbm.2017.12.029.

[21] Prummer, R. (2006). Explosive compaction of powders and composites. CRC Press.

[22] Deqing, W. and Ziyuan, S. (2003). Effect of ceramic particles on cell size and wall thickness of aluminum foam. Materials Science and Engineering: A, 361(1-2), pp. 45-49. DOI: 10.1016/S0921-5093(03)00557-4.

[23] Lankford, J. and Dannemann, K. A. (1998). Strain rate effects in porous materials. MRS Online Proceedings Library Archive, 521. DOI: 10.1557/PROC-521-103.

[24] Takayama, K. (1995). Optical flow visualization of shock wave phenomena (Paul Vieille Memorial Lecture). In Shock Waves@Marseille IV, Springer, Berlin, Heidelberg pp. 7-16. DOI: 10.1007/978-3-642-79532-9_2.

[25] Duff, R. E. and Blackwell, A. N. (1966). Explosive driven shock tubes. Review of Scientific Instruments, 37(5), pp. 579586. DOI: $10.1063 / 1.1720256$

[26] Itoh, S., Hamashima, H., Murata, K. and Kato, Y. (2002). Determination of JWL parameters from underwater explosion test. In 12th International Detonation Symposium, 281, DOI: 10.1080/07370652.2020.1822461.

[27] Lyras, G., Herrmann, T. A. and Nackino, A. (2018). U.S. Patent No. 10,092,996. Washington, DC: U.S. Patent and Trademark Office.

[28] Carroll, M. M. and Holt, A. C. (1972). Static and dynamic pore-collapse relations for ductile porous materials. Journal of Applied Physics, 43(4), pp. 1626-1636. DOI: 10.1063/1.1661372.

[29] Deshpande, V. S. and Fleck, N. A. (2000). High strain rate compressive behaviour of aluminium alloy foams. International Journal of Impact Engineering, 24(3), pp. 277-298. DOI: 10.1016/S0734-743X(99)00153-0.

[30] Autodyn, “Theory Manual,” Century Dynamics INS: Revision, (2005).

[31] Mukai, T., Kanahashi, H., Higashi, K., Yamada, Y., Shimojima, K., Mabuchi, M. and Nieh, T. G. (1999). Energy absorption of light-weight metallic foams under dynamic loading. In MetFoam 99: International Conference on Metal Foams and Porous Metal Structures, pp. 353-358.

[32] Hall, I. W., Güden, M. and Yu, C. J. (2000). Crushing of aluminum closed cell foams: density and strain rate effects. DOI: $10.1016 /$ S1359-6462(00)00460-7 
[33] Dannemann, K. A., Lankford Jr, J. and Nicholls, A. E. (2002, July). The Mechanism of Strain Rate Strengthening during Dynamic Compression of Closed-Cell Aluminum Foam. In AIP Conference Proceedings, American Institute of Physics. 620(1), pp. 729-734. DOI: 10.1063/1.1483641.

[34] Izadpanah Najmabad, S., Gerdooei, M. and Ghaderi, S. H. (2016). Determination of BBC2003 yield criterion constants for anisotropic aluminum alloy sheets based on plane strain tensile test. Modares Mechanical Engineering, 15(11), pp. 127-135. https://mme.modares.ac.ir/article-15-4775-en.html

[35] Zhou, Q., Chen, P. W. and Ma, D. Z. (2013). Tungsten-Copper Composite Fabricated by Hot-Shock Consolidation. In Materials Science Forum Trans Tech Publications Ltd. 749, pp. 372-377.

DOI : $10.4028 /$ www.scientific.net/MSF.749.372.

[36] Gray, G. T. R., Maudlin, P. J., Hull, L. M., Zuo, Q. K. and Chen, S. R. (2005). Predicting material strength, damage and fracture the synergy between experiment and modeling. Journal of Failure Analysis and Prevention, 5(3), pp. 7-17. DOI: $10.1361 / 15477020523725$.

[37] Rahimzadeh, T., Arruda, E. M. and Thouless, M. D. (2015). Design of armor for protection against blast and impact. Journal of the Mechanics and Physics of Solids, 85, pp. 98-111. DOI: 10.1016/j.jmps.2015.09.009.

[38] Petrudi, A. M., Fathi, P. and Rahmani, M. (2020). Multi-objective Optimization to Increase Nusselt Number and Reduce Friction Coefficient of Water/Carbon Nanotubes via NSGA II using Response Surface Methodology. Journal of Modeling and Simulation of Materials, 3(1), pp. 1-14. DOI: 10.21467/jmsm.3.1.1-14.

[39] Moslemi Petrudi, A., Vahedi, K., Kamyab, M. H. and Petrudi, M. (2019). Numerical and Experimental Study of Oblique Penetration of a Blunt Projectile into Ceramic-Aluminum Target. Modares Mechanical Engineering, 19(5), pp. 12531263. https://mme.modares.ac.ir/article-15-20854-en.html

[40] Petrudi, A. M., Vahedi, K., Rahmani, M. and Petrudi, M. M. (2020). Numerical and analytical simulation of ballistic projectile penetration due to high velocity impact on ceramic target. Frattura ed Integrità Strutturale, 14(54), pp. 226248. DOI: $10.3221 /$ IGF-ESIS.54.17.

[41] Rahmani, M. and Petrudi, A. M. (2020). Optimization and Experimental Investigation of the Ability of New Material from Aluminum Casting on Pumice Particles to Reduce Shock Wave. Periodica Polytechnica Mechanical Engineering, 64(3), pp. 224-232. DOI: 10.3311/PPme.15983. 